\title{
SIGNIFICACIÓN Y TRASCENDENCIA DEL GÉNERO EPISTOLAR EN LA POLÍTICA CORTESANA: LA CORRESPONDENCIA INÉDITA ENTRE LA INFANTA ISABEL CLARA EUGENIA Y EL MARQUÉS DE VELADA*
}

\author{
por \\ SANTIAGo MARTÍNEZ HERNÁNDEZ \\ Real Biblioteca, Madrid
}

RESUMEN: El principal objetivo del presente artículo es dar a conocer parte de la correspondencia inédita conservada entre la infanta Isabel Clara Eugenia y el marqués de Velada - su mayordomo mayor durante once años- a lo largo de los primeros años del siglo XVII. La progresiva utilización por parte de la historiografía de la corte de los epistolarios privados ba puesto de relieve su importancia como fuentes documentales de primer orden frente a la correspondencia oficial. El contenido de las cartas particulares suele ofrecer una información que aporta matices, juicios y valoraciones personales que por la libertad con que son emitidos, merced a su confidencialidad, resultan de un valor mucho mayor al recogido en la documentación pública. Indudablemente las cartas fueron algo más que transmisoras de noticias, convirtiéndose en un poderoso nexo de unión, en un estrecho vínculo que permitía mantener relaciones en la distancia. El ejemplo que presentamos a continuación permite conocer algunos aspectos de la importancia que la correspondencia tuvo en la consolidación de la relación política y personal entre dos personalidades diferentes en cuanto a condición social y género.

Palabras clave: Cartas. Corte. Escritura privada. España. Siglos XVI y XVII.

* Este artículo debe mucho al consejo y magisterio del profesor Fernando Bouza cuya generosidad nunca será suficientemente agradecida. Igualmente quisiera hacer constar mi deuda de gratitud con el profesor Bernardo García y con Pablo Andrés Escapa por su inestimable ayuda en la conclusión de este trabajo. Abreviaturas utilizadas: AGP [Archivo General de Palacio, Madrid], BL [British Library, Londres; Additional], BNM [Biblioteca Nacional, Madrid], BPUG [Bibliothèque publique et universitaire, Ginebra; Collection Edouard Favre], BZ [Biblioteca Francisco de Zabálburu y Besabé, Madrid; Fondo Altamira], CoDoIn [Colección de Documentos Inéditos para la Historia de Espa$\tilde{n} a$ ], IVDJ [Instituto Valencia de Don Juan, Madrid], RB [Real Biblioteca, Madrid].

Hispania, LXIV/2, núm. 217 (2004) 467-514 
ABSTRACT: The aim of this paper is make known the unpublished correspondence maintained between the Infanta Isabel Clara Eugenia and the Marquis of Velada, her lord bigh steward for a period of eleven years in the early seventeenth century. This private correspondence has become a vital source of information, especially for the historiography of the court, specifically in comparison with official correspondence. The content of the letters brings nuance and personal judgements which, by virtue of the freedom with which they were written, prove to have a much greater value than the public documents. Certainly, the letters not only transmitted news but also became a powerful means for maintaining the relationship over a considerable distance. This correspondence provides a number of insights into the political and personal relations between a princess and a courtier. The article also includes a transcription and abstract of the letters.

KEY WORDS: Letters. Court. Private handwriting. Spain. XVI ${ }^{\text {th }}-X{ }^{2} I^{\text {th }}$ centuries.

Para Esther $O$ litteras tuas, et amicas et sensibus argutas...1

«Dos cartas vuestras e reçybydo estos dýas y olgado mucho con ellas, que son las más frescas nuebas que e tenydo de aý»2.

Desde Roma, en donde ejercía como embajador de Felipe II ante Pío V, un lastimero Juan de Zúñiga reclamaba a su amigo Juan de Silva nuevas con las que aliviar su reciente soledad diplomática pues «no ay otro regalo para las pesadumbres desta corte si no las cartas de los amigos» ${ }^{3}$. Semejante ruego no obedecía únicamente a la urgencia de permanecer informado de cuanto ocurría en su corte natal a través de cauces oficiosos y casi siempre solventes sobre los que sostener sus actuaciones políticas, sino a la necesidad de «conversar» con sus «amigos» en la distancia a través de aquellas cartas. Para Zúñiga esa «necesidad de sus cartas», que también requería a Fernando de Toledo, le permitía soslayar el aislamiento político y emocial que padecía sirviendo al rey alejado de la corte, por lo que apremiaba a sus corresponsales para que le avisaran «muy particularmente de todo lo de allá», rogando que las misivas «vengan muy a menudo» ${ }^{4}$.

\footnotetext{
1 Carta de Justo Lipsio a Francisco de Quevedo, Lovaina, 22 de febrero de 1605, Quevedo, Francisco de: Obras, colección completada, corregida, ordenada e ilustrada por Aureliano Fernández-Guerra y Orbe, Madrid, M. Rivadeneyra, 1876, Biblioteca de Autores Españoles, tomo II, carta II, p. 512.

2 Carta de la infanta Isabel al marqués de Velada, Mariemont, 23 de mayo de 1615, BL, Add. 28.698, fols. $199 \mathrm{r}-200 \mathrm{v}$

3 Carta de Juan de Zúñiga a Juan de Silva, Roma, 13 de febrero de 1568, Codorn, Madrid, 1890, vol. XCVII, pp. 396-397.

4 Carta de Juan de Zúñiga a Fernando de Toledo, Roma, 7 de febrero de 1568, ibidem, pp. 394-395.
}

Hispania, LXIV/2, núm. 217 (2004) 467-514 


\section{El GÉNERo EPISTOLAR. Prácticas de ESCRITURA Y MODELOS DE RELACIÓN}

Desde no hace mucho tiempo los epistolarios particulares o privados han comenzado a valorarse como fuentes documentales de primer orden por una historiografía que con frecuencia los había marginado de la investigación al considerarlos recursos estrictamente literarios 5 . Pese a todo, el período cronológico que nos ocupa, el que abarca el reinado de Felipe III, ha resultado ser uno de los más prolíficos en correspondencia disponiendo los historiadores de la edición de conjuntos epistolares de gran valor. Entre ellos cabe destacar la correspondencia de Felipe III con su hija la reina Ana de Francia a cargo de Ricardo Martorell ${ }^{6}$, la de la infanta Isabel Clara Eugenia con el duque de Lerma al cuidado de Antonio Rodríguez Villa ${ }^{7}$, la intercambiada entre el duque de Sessa y Lope de Vega de Agustín González de Amezúa ${ }^{8}$, las cartas de Luis de Góngora $^{9}$ y la de Luisa de Carvajal y Mendoza (1598-1613) ${ }^{10}$, entre otras. También cabría incluir aquí, aunque carezcan de edición y estudio introductorio, la transcripción de la correspondencia del archiduque Alberto con Francisco de Mendoza, almirante de Aragón, y con el duque de Lerma recogida en los volúmenes XLI y XLII, y XLII y XLIII respectivamente de la Colección de documentos inéditos para la Historia de España ${ }^{11}$.

5 Domínguez OrTiz, Antonio, prólogo al Epistolario del conde de Tendilla (1504-1506), estudio a cargo de José Szmolka Clares, edición y transcripción al cuidado de $\mathbf{M}^{\mathrm{a}}$ Amparo Moreno Trujillo y $\mathrm{M}^{\mathrm{a}}$ José Osorio Pérez, Granada, Servicio de Publicaciones de la Universidad de Granada, 1996, 2 vols., pp. VII-XI. El propio epistolario de Lope de Vega con el duque de Sessa es analizado por Agustín González de Amezúa desde la más estricta crítica literaria dejando de lado la importancia que tales cartas tienen para la historiografía política, GONZÁLEZ DE AMEZÚA Y MAYO, Agustín: Lope de Vega en sus cartas, Madrid, 1935-1943, 4 vols. Sin embargo, recientemente se ha puesto de manifiesto la importancia que las cartas de literatos pueden tener por su contenido histórico y documental. Para el caso de Quevedo véase SÁNCHEZ SÁNCHEZ, Mercedes: «Lo público y lo privado: acerca del epistolario de Quevedo» en Edad de Oro (Madrid) XII (1993) pp. 293-301. Últimamente la correspondencia ha sido objeto de análisis en el VI Congreso Internacional de Historia de la Cultura Escrita organizado por la Universidad de Alcalá de Henares, el vol. I de las Actas está dedicado a $L a$ Correspondencia en la Historia. Modelos y prácticas de la escritura epistolar, edición a cargo de SÁEZ, Carlos y CASTILlo Gómez, Antonio, Alcalá de Henares, Biblioteca Litterae- Editorial Calambur, 2002.

${ }^{6}$ Martorell TÉllez Girón, Ricardo: Cartas de Felipe III a su bija Ana, Reina de Francia, 1616-1618, Madrid, Edición Moderna, 1929.

7 RODRígueZ VILla, Antonio: Correspondencia de la Infanta Archiduquesa doña Isabel Clara Eugenia de Austria con el Duque de Lerma y otros personajes, Madrid, Establecimiento Tipográfico de Fortanet, 1906,

8 Vid. supra nota 5.

9 GÓNGORA, Luis de: Epistolario completo, edición a cargo de Antonio Carreira, concordancias de Antonio Lara, Zaragoza, Libros Pórtico, 2000.

${ }^{10}$ Carvajal y Mendoza, Luisa de: Epistolario y poesía, edición y estudio de Jesús González de Marañón y Camilo María Abad, Madrid, BAE, ed. Atlas, 1965.

11 Madrid, 1863, tomo 41 (pp. 421-556), $42(5-217,218-573)$ y 43 (5-232), recogido en ThомAs, Werner, «La Corte de los archiduques Alberto de Austria y la infanta Isabel Clara Euge- 
Expresión más que elocuente de la importancia concedida a los epistolarios como fuentes históricas de consulta ineludible es el proyecto de catalogación que la Real Biblioteca de Madrid emprendió hace algunos años, concluido recientemente, de la abundantísima colección de cartas - aproximadamente unas treinta mil- enviadas y remitidas al conde de Gondomar, Diego Sarmiento de Acuña (1567-1626), dos veces embajador en Londres con el tercero de los Felipes ${ }^{12}$.

Resulta evidente la enorme significación que el género epistolar aporta a cualquier investigación histórica y más aún si se tiene presente la trascendencia de las, a menudo, valiosas informaciones contenidas en la correspondencia privada por las argumentaciones y juicios personales que a los corresponsales merecen los hechos que en ellas relatan con la libertad y confianza que amparaba la comunicación a través de un texto manuscrito ${ }^{13}$. Por ello, la correspondencia es un elemento de imprescindible consulta para profundizar no sólo en la naturaleza de las relaciones familiares sino también en las políticas y de amistad. Las cartas intercambiadas entre hombres de estado, entre cortesanos, a los que unen lazos de amistad o simplemente intereses políticos comunes, siempre merecen el privilegio de la confidencia y por lo tanto aportan, sin lugar a dudas, testimonios de un valor mucho mayor a los recogidos en la bien conocida correspondencia oficial.

La correspondencia que desde Cicerón, padre del género epistolar moderno, había alcanzado la consideración, incluso, de modelo literario ${ }^{14}$, se convirtió a lo largo de la Edad Moderna en el principal transmisor de noticias, en el más libre y eficaz cauce de información, y pese a existir toda una tratadística que regulaba y racionalizaba la práctica de la escritura privada, quedaba al libre albedrío de cada corresponsal la forma de comunicarse en función del grado de

\footnotetext{
nia en Bruselas (1598-1633). Una revisión historiográfica» en CRESPO SOLANA, Ana y Herrero SÁNCHEZ, Manuel (coords.): España y las 17 provincias de los Países Bajos. Una revisión historiográfica (XVI-XVIII), Córdoba, Universidad de Córdoba, Ministerio de Asuntos Exteriores y Fundación Carlos de Amberes, 2002, vol. I, p. 355-386.

${ }_{12}$ Son ya tres los volúmenes publicados quedando pendiente el cuarto y último de breve aparición. LÓPEZ-VIDRIERO, María Luisa (dir.): Catálogo de la Real Biblioteca. Tomo XIII. Correspondencia del Conde de Gondomar, Madrid, Patrimonio Nacional, vols. I y II (1999), vol. III (2002) y vol. IV (2003).

${ }_{13}$ Sobre la importancia de la correspondencia particular de la nobleza cortesana y su indudable valor como fuente para el conocimiento de los usos y costumbres de la corte y de sus protagonistas se ha ocupado el profesor BouZA Álvarez, Fernando: Corre manuscrito. Una bistoria cultural del Siglo de Oro, Madrid, Marcial Pons, 2001, en especial en el capítulo IV, «Cartas secas y cartas nuevas. Lo que hay de nuevo que avisar es...", pp. 137-177; y en "Cortes festejantes. Fiesta y ocio en el cursus bonorum cortesano», Manuscrits (Barcelona) 13 (1995) pp. 185-203.

${ }_{14}$ Mestre SANCHís, Antonio: «La carta, fuente de conocimiento histórico», en Revista de Historia Moderna. Anales de la Universidad de Alicante, Epistolarios. Correspondencia (Alicante) 18 (1999. 2000) pp. 13-26. También TRUEBA LAWAND, Jaime: El arte epistolar en el Renacimiento español, Londres, Tamesis Book, 1997 y CHARTIER, Roger: Correspondance: models for letter-writing from the Middle Age to the nineteenth century, Princeton, Princeton University Press, 1997.
} 
relación establecido previamente con el destinatario ${ }^{15}$. Durante el Siglo de Oro las cartas se erigieron en la práctica de escritura más frecuente dentro del ámbito privado, en «una de las manifestaciones del escribir subjetivo y existencial» ${ }^{16}$.

Las relaciones epistolares entre cortesanos y nobles en general, entre quienes mantenían una amicitia política o vínculos familiares, se desarrollaron dentro de unos parámetros definidos en la tradición de la comunicación oral. En las cartas las palabras eran medidas, cuidadas, tal era la importancia de la correspondencia entre iguales. Por ello se respetaba escrupulósamente en ellas los principios del arte de conversar ${ }^{17}$, manteniéndose en todo momento la estructura sobre la que se sustentaba cualquier conversación cortés, y siendo las letras el reflejo escrito de las palabras que ambos corresponsales se dirigían en la atemporalidad que imponía la distancia. Ya Luis Vives había caracterizado la carta como una «conversación entre personas ausentes por medio de la escritura» con la que "poder transmitir a otros las propias ideas y pensamientos, siendo así fiel intérprete y mensajera entre los hombres» ${ }^{18}$.

Las cartas fueron un elemento imprescindible tanto para el mantenimiento de las relaciones familiares y de amistad, en la distancia, y la consolidación de alianzas políticas como para la transmisión de noticias e informaciones, máxime si se tiene en cuenta la lentitud de las comunicaciones y los inconvenientes derivados de las largas y, a menudo, peligrosas jornadas que los correos recorrían para entregar su valiosa mercancía ${ }^{19}$. El caso que nos ocupa, la relación episto-

is Véase al respecto Gimeno BlAY, Francisco M.: «Missivas, mensageras, familiares... Instrumentos de comunicación y de gobierno en la España del quinientos", en CASTILlo Gómez, Antonio (comp.): Escribir y leer en el siglo de Cervantes, Barcelona, Gedisa, 1999, pp. 193-209.

16 CASTILlO GÓMEZ, Antonio: «Como o polvo e o camaleão se transformam. Modelos e práticas epistolares na Espanha Moderna», en BASTOS, María Helena Camara, CUNHA, Maria Teresa Santos y Mignot, Ana Chrystina Venancio (coords.): Destino das letras. História, educação e escrita epistolar, Brasil, Editora Universitaria, Universidade de Passo Fundo, Brasil, [s.a.], pp. 13-56; del mismo también «Entre public et privé. Stratégies de l'escrit dans l'Espagne du Siècle d'Or» en Annales. Histoire, Sciences Sociales (París) 4-5 (juillet-octobre 2001) pp. 803-829.

17 BOUZA Álvarez, Fernando, «Escribir en la corte. La cultura de la nobleza cortesana y las formas de comunicación en el Siglo de Oro», en BENASSAR PERILLIER, Bartolomé y otros, Vivir el Siglo de Oro. Poder, cultura e Historia en la época moderna. Estudios en homenaje al profesor Ángel Rodríguez Sánchez, Salamanca, Universidad de Salamanca, pp. 77-100.

18 VIVES, Juan Luis: Epistolario, edición a cargo de José Jiménez Delgado, Madrid, Editora Nacional, 1978, pp. 599-602, citado por CASTILlo GómEZ, Antonio: «La fortuna de lo escrito. Funciones y espacios de la razón gráfica (siglos XV-XVII), Bulletin Hispanique (Burdeos) 100- 2 (1998) p. 358. Del mismo «Del tratado a la práctica. La escritura epistolar en los siglos XVI y XVII», en SÁEZ y CASTILlo GómeZ (eds.), op. cit., pp. 79-107.

19 Resulta incuestionable el innumerable valor de las informaciones que incluía en sus cartas, verdaderas relaciones de sucesos, Andrés de Almansa y Mendoza, véanse sus célebres Cartas de Andrés de Almansa y Mendoza. Novedades de esta Corte y avisos recibidos de otras partes, 1621-1626, en Colección de Libros españoles raros o curiosos, tomo XVII, Madrid, Imprenta Miguel Ginesta, 1886. También GOTOR, José Luis: «Formas de comunicación en el siglo XVI (relación y carta)», El Libro Antiguo Español, Actas del primer Coloquio Internacional, al cuidado de LóPEZ-VIDRIERO, María Luisa y 
lar entre la infanta Isabel Clara Eugenia y el marqués de Velada —un antiguo servidor $^{20}$ - , bien sirve de ejemplo para analizar el sostenimiento de una relación política en la distancia. A las limitaciones espacio-temporales existentes entre las ciudades de Madrid y Bruselas, lugar donde residían habitualmente ambos corresponsales, y pese a ser considerada por la corte española la comunicación con esta última como absolutamente preferente, se unían los frecuentes extravíos, robos y secuestros de la correspondencia, que ni siquiera conseguía eludir la presunta inmunidad de los correos reales cuando atravesaban reinos supuestamente amigos $^{21}$, cuando no la siempre celosa supervisión de los hombres de confianza de los ministros del rey ${ }^{22}$.

La carta, pues, como todo manuscrito en general, permitía el «secreto y la deferencia» que requería la transmisión de informaciones al tiempo que facili-

CÁtedra, Pedro $\mathrm{M}^{\mathrm{a}}$, Salamanca, Ediciones Universidad de Salamanca, Biblioteca Nacional de Madrid, Sociedad Española de Historia del Libro, 1988, pp. 175-188.

20 Sobre su personalidad y trayectoria política nos venimos ocupando desde hace varios años. Véase: «La nobleza cortesana en el reinado de Felipe II: Don Gómez Dávila y Toledo, segundo Marqués de Velada, una carrera política labrada al amparo de la corona», Torre de los Lujanes 33 (abril 1997) pp. 185-220; Los libros del Ayo y Mayordomo Mayor del Rey. La biblioteca del Marqués de Velada, don Gómez Dávila y Toledo (c. 1535-1616); Madrid, UCM, 1998 (Memoria de Licenciatura inédita); «Semblanza de un cortesano instruido: El Marqués de Velada, ayo del Príncipe Felipe (III), y su biblioteca», Cuadernos de Historia Moderna 22 (1999) pp. 53-78; "Pedagogía en Palacio: el Marqués de Velada y la educación del Príncipe Felipe (III), 1587-1598", Reales Sitios, 142 (4 trimestre 1999), pp. 34-59; «El servicio al rey. De la milicia a la corte: don Fernando de Toledo y Dávila (c. 1538-1602)», en MARTínez Ruiz, Enrique, dir.: Madrid, Felipe II y las ciudades, tomo II, Las ciudades: capitalidad y economía, Madrid, 2000, pp. 123-133; "La biblioteca del convento de San Antonio de Padua de Velada (Toledo): origen y fortuna de la Librería Grande de los marqueses de Velada», Archivo Ibero-Americano 235 (enero-abril de 2000) pp. 35-68; Gómez Dávila y Toledo, II Marqués de Velada, y la corte en los reinados de Felipe II y Felipe III, Tesis Doctoral inédita, Madrid, Universidad Complutense de Madrid, 2002; «La hacienda del marqués de Velada. Perfiles de una economía cortesana», Cuadernos de Historia Moderna (2004) en prensa; "Obras... que hazer para entretenerse. La arquitectura en la cultura nobiliario-cortesana del Siglo de Oro: a propósito del marqués de Velada y Francisco de Mora", Anuario del Departamento de Historia y Teoría del Arte (U.A.M) Vol. XV (2003) pp. 59-77; «Memoria y escritura privada en la cultura nobiliario-cortesana del Siglo de Oro: los papeles del Marqués de Velada», Peninsula. Revista de Estudos Ibéricos, 1 (2004), pp. 395-422.

21 «Marqués, aún creo que abrá correo presto. Me dyçen yrán más syguras las cartas con el ordynaryo por estar rebueltas de Françya», carta de la infanta Isabel al marqués de Velada, Bruselas, 24 de noviembre de 1615, IVDJ, Envío 38, Caja 50, doc. 86.

22 «Marqués, no e osado fiar de correos esta carta por que todos pasan por mano de don Rodrigo [Calderón] y asý e aguardado a que la llebe el de Fyerstenberg, que la dé en vuestras manos», Bruselas, 14 de septiembre de 1612, BL, Add. 28.698, fols. 185r-186v. La correspondencia entre Felipe IV y sor María de Jesús de Ágreda está repleta de alusiones a las limitaciones que imponía la comunicación por carta que no era siempre el modo más apropiado para expresar determinados pensamientos o reflexiones. A menudo confiaron los papeles y las cartas más comprometedores a portadores de la mayor confianza, CASTILlo GómEZ, «Entre public et privé», art. cit., p. 821.

Hispania, LXIV/2, núm. 217 (2004) 467-514 
taba una mayor proximidad entre los corresponsales ${ }^{23}$. En la propia esencia de la correspondencia privada hológrafa estaba implícita una voluntad evidente de trascender la siempre obligada relación de cortesía entre remitente y destinatario y alcanzar así una mayor libertad en esa suerte de "conversación» escrita que facilitaba el papel ${ }^{24}$. Las cartas fueron, por ello, un instrumento esencial e indispensable en las alianzas y vínculos establecidos entre los miembros de la corte sirviendo de privilegiado «canal para el vital envío de informaciones y para el mismo ejercicio de solidaridad entre sus miembros» e incluso también, en muchos casos, el origen de las redes o bandos cortesanos ${ }^{25}$. Indudablemente, el caso que abordamos aquí, la correspondencia privada - signo indiscutible de la sociabilidad y cortesía nobiliaria ${ }^{26}$ - contribuyó a conservar y consolidar los vínculos de la infanta con la corte española, a través de un corresponsal de primer orden, el que fuera su mayordomo mayor desde 1587, y a la inversa permitió al marqués de Velada continuar manteniendo relación estrecha con doña Isabel, quien había sido y continuaría siendo una aliada política muy valiosa que, aunque en la distancia, favoreció sus inmediatas pretensiones políticas.

Desde Flandes la infanta, siempre pendiente de cuanto acontecía en Madrid, no parecía nunca colmada de las informaciones recibidas y no se contentaba únicamente con las que recibía a través de la correspondencia oficial. Resultaba vital para ella y para su marido obtener nuevas de la corte casi a diario, por lo que también establecieron cauces de información ajenos a los estrictamente oficiales; Velada fue uno de ellos ${ }^{27}$. No obstante, mantuvieron una estrecha colaboración con el duque de Lerma, pues era él quien marcaba la política seguida por Felipe III y en su voluntad se cifraban las necesidades y las

${ }^{23}$ Un ejemplo más que representativo de la importancia de la correspondencia particular son las cartas de Felipe II a sus hijas. Sobre el notable cambio de estilo de las cartas del rey en sus relaciones familiares en comparación con la correspondencia de estado y el valor que concedía el rey a la relación epistolar con sus parientes más próximos, véase BouZA Álvarez, Fernando (ed.): Cartas de Felipe II a sus hijas, Madrid, Akal, 1998.

${ }^{24}$ ARIÈs, Philippe: «Para una historia de la vida privada», en ARIÈs, Philippe y DuBY, Georges (dirs.): Historia de la vida privada, vol. V, El proceso de cambio en la sociedad de los siglos XVI-XVIII, Madrid, Taurus, 1992, p. 11, citado por BOUZA ÁlVAREZ, Cartas, pp. 12-13 (en la edición francesa de París, 1986). De la importancia de la correspondencia privada en las relaciones amorosas y de amistad se ocupó RANUM, Orest: «Los refugios de la intimidad», ARIÈS y DUBY, op. cit., pp. 212-265.

${ }_{25}$ Teniendo en cuenta esta premisa cabría preguntarse si la actual historiografía sobre la corte se está ocupando como debiera del estudio y análisis de la correspondencia particular como fuente de primer orden para el conocimiento de la formación, consolidación o ruptura de las principales facciones así como de las relaciones entre sus miembros.

${ }^{26}$ CARDim, Pedro: $O$ poder dos afectos. Ordem amorosa e dinâmica política no Portugal do Antigo Regime, Lisboa, Universidade Nova de Lisboa, 2000 (tesis doctoral inédita), p. 431.

27 «Marqués, cuatro o çynco cartas e reçybydo vuestras con que e olgado mucho pero no de que no ayan llegado a mys manos las dos que me avysáys de 26 y 29 de nobyembre en que me deçýades de los casamyentos del Almyrante y el de Çea para que aunque reys por donde se encamynan las cartas con todas las nuebas que me dáys en estas e olgado mucho", carta de la infanta Isabel al marqués de Velada, Bruselas, 1 de marzo de 1613, BL, Add. 28.698, fols. 187r-188v. 
esperanzas de gobierno de los archiduques. Esto se tradujo en una rica y prolongada relación epistolar en la que la cercanía entre los corresponsales confirma una comunicación íntima y amistosa, más allá de la mera colaboración política como escribía la infanta al duque de Lerma al confirmarle que aunque hubiese recibido «un correo de particulares, no me contento con eso hasta tener cartas» ${ }^{28}$. Esa confianza en la recepción regular de correspondencia se tornaba en dependencia para quien se encontraba alejado del principal centro de poder o incluso para quien sin estarlo le urgía conocer cuanto pudiera tener relación con sus futuras pretensiones o aspiraciones cortesanas. En este sentido, el conde de Nieva escribía desde Valladolid al marqués de Velada agradeciéndole «la relaçión que de todo" lo que hacía Felipe III en sus jornadas le daba pues «traygo tan pocos coronistas que todavía me a aliviado ver la carta de VS» ${ }^{29}$.

La necesidad de corresponsales dignos de confianza resultaba ser, para quienes mantenían varios cauces de información, una cuestión de enorme trascendencia en la que no se escatimaba ni en gastos ni en escrúpulos pues de ello dependía la suerte política de quien de ellos se beneficiaba. A propósito de esta preocupación el ya mencionado Juan de Zúñiga había acordado con su hermano Luis de Requesens que

«el agente que quedare en la corte $[\ldots]$ es menester que tenga salario mío, y muy gran correspondencia conmigo cuando VS navegue, y que quede muy conocido de Villegas y de don Cristóbal [de Moura], de don Juan de Cárdenas y de los otros amigos míos que ahí quedaren» 30 .

Tenía la correspondencia un valor extraordinario para la información pero también para la crítica y la ironía, cuestión ésta que asumían cuantos en la corte andaban, siempre aprendiendo de avezados maestros en el arte de la diatriba cortesana como Diego Hurtado de Mendoza quien había afirmado, según recordaba Juan de Silva a Cristóbal de Moura, «la ventaja con que se refieren las cosas por escripto [...] que diziendo lo que se haze en público no se puede mentir tan honrradamente ${ }^{31}$. Precisamente este valor de reserva y secreto hacía de las cartas un arma muy poderosa, y a la vez peligrosa, para quien las poseía, y por ello cuando el contenido podía resultar comprometedor se tomaban las oportunas medidas de seguridad para evitar cualquier extravío o desapa-

${ }_{28}$ Carta de la infanta Isabel al duque de Lerma, Bruselas, 22 de octubre de 1606, en RoDRíGUEZ VILLA, op. cit., carta 109, pp. 160-161.

29 Valladolid, 25 de mayo de 1603, IVDJ, Envío 86, Caja 121, doc. 484.

${ }^{30}$ Carta de Juan de Zúñiga a Luis de Requesens, Roma, 21 de abril de 1568, CoDolN, XCVII, pp. 439-442.

31 «Bien dezía don Diego de Mendoça de la ventaja con que se refieren las cosas por escripto, mas díxolo por lo que escrivimos, diximos que diziendo lo que se haze en público no se puede mentir tan honrradamente», carta de Juan de Silva a Cristóbal de Moura, 27 de septiembre de 1597, BNM, Ms. 6.198, fol. 25r. 
rición inoportuna. Entre las más habituales estaba la de acudir a personas de máxima confianza para hacer de correos entre remitente y destinatario ${ }^{32}$, escribir la respuesta en la misma carta y devolverla por los mismos cauces al remitente, o, una de las más comunes, destruirla. Muchas cartas, comprometedoras sin duda, han llegado hasta nosotros porque finalmente o bien se devolvieron a sus remitentes o bien no fueron destruidas, incumpliendo así la voluntad de sus autores, pero permitiéndonos tener acceso a una información, en la mayoría de los casos, muy valiosa ${ }^{33}$.

A través de la numerosísima correspondencia particular conservada del marqués de Velada puede observarse hasta qué punto estimaba su privacidad epistolar. La condición sine qua non para iniciar y consolidar una relación epistolar era la confidencialidad, aunque algunos olvidaran tan importante consideración, como le reprochó el marqués, en cierta ocasión, a Cristóbal de Moura, a quien dijo: "no huelgo que mis cartas las vea otro que para quien van» ${ }^{34}$.

No debió olvidar la lección el caballero portugués cuando en ocasión similar sorprendió a Francisco de Rojas, marqués de Poza: «si el Marqués de Velada supiese que VS abre las cartas agenas no dejaría de confesar que es hombre de pecho»35.

Junto a la obligada privacidad de las epístolas, la naturaleza de la escritura perfilaba el grado de confianza que al remitente merecía el destinatario. Así, las cartas hológrafas eran una muestra de deferencia y cortesía entre corresponsales y por ello resultaba casi obligado - si existía una relación personal estrechasaberse excusar cuando se acudía a mano ajena; a menudo por motivos de salud o cuando la descuidada caligrafía convertía la satisfacción de su apertura en fatiga para la vista y desconsuelo para el ánimo. Escribía en este sentido el duque de Medinaceli a Quevedo que habiendo concluido una carta para él de su mano, viendo que era de "tan mala letra la hiçe copiar»".6. El propio marqués de Velada había rogado a su hermano el obispo Sancho Dávila que le remitiera sus cartas por mano de secretario a lo que éste había respondido en cierta ocasión que "por obedeçer a VS no escrivo ésta de mi mano» ${ }^{37}$. En otras circuns-

${ }^{32}$ Vid. supra nota 22.

33 Sobre la condición de los archivos como custodios de la memoria escrita y la utilización de sus fondos documentales con fines poco ortodoxos, véase BOUZA ÁlvarEZ, Fernando: Imagen y propaganda. Capitulos de historia cultural de Felipe II, prólogo de Roger Chartièr, Madrid, Akal, 1998, pp. 43-50. Ejemplos sobre los ruegos para devolver las cartas al remitente o destruirlas hay centenares, he aquí algunos referidos a cartas hológrafas enviadas por el marqués de Velada a su hija la duquesa viuda de Medinaceli: «este papel se queme en leyéndose», 14 de septiembre de 1614, IVDJ; Envío 95, Caja 137, doc.132; y "bolverásme con éste esta carta porque me quede razón», ibidem, San Lorenzo, 8 de agosto de 1614, ibidem, Envío 86, caja 121, doc. 498.

3412 de abril de 1583, BPUG, Favre, vol. XXXV, fols. 14r.- $15 \mathrm{v}$.

35 Carta de Cristóbal de Moura al marqués de Poza, San Lorenzo, 19 de octubre de 1596, BNM, Ms. 6.178, fols. 45r.-v

${ }^{36}$ Sevilla, 5 de abril de 1644, QuEvedo, op. cit., carta CXXXIII, pp. 608-609.

${ }_{37}$ Jaén, 26 de septiembre de 1602, BZ, Altamira, Carpeta 196, doc. 120. 
tancias, cuando sólo se enviaban informaciones y relaciones breves de sucesos, sin mayores pretensiones argumentales, ni confidencias, a menudo se acudía a letra de secretarios. Así lo entendía Velada al escribir a su hija la duquesa viuda de Medinaceli que «todo lo que es dar nuevas de acá y del mundo he escrito en una carta larga de mano ajena» ${ }^{38}$.

Así pues, si el "grado de solemnidad y privacidad» ${ }^{39}$ entre remitente y destinatario se medía en función del número de renglones que de propia mano se dedicaban, a juzgar por la muestra epistolar conservada - de la que la totalidad de las cartas de doña Isabel son hológrafas desde la primera a la última letra-, parece que entre el marqués de Velada y la infanta Isabel existió un estrecho entendimiento. Asimismo por las referencias que figuran en las misivas de las cartas enviadas y recibidas la frecuencia epistolar entre ambos corresponsales debió ser elevada. Desgraciadamente tan solo ha llegado hasta nosotros una pequeña parte de aquella correspondencia aunque constituye, no obstante, un sabroso testimonio del género epistolar cortesano. La totalidad de las cartas aquí recogidas proceden del archivo de la Casa de Velada, uno más de la antigua Colección Altamira, donde se han conservado hasta nuestros días. Curiosamente el grueso de las cartas, una quincena, ha permanecido en la British Library de Londres procedente del lote documental que adquirió a Federico Disdier en el siglo XIX ${ }^{40}$. Resulta paradójico que el conde de Valencia de Don Juan, que se hizo con una parte importante de dicha Colección, entre ella muchos autógrafos célebres, no seleccionara las cartas hológrafas de la infanta para sí. No obstante, en la biblioteca del Instituto Valencia de Don Juan se han conservado dos, una fechada en el verano de 1573, y que ya publicara Llanos y Torriglia en su biografía de Isabel ${ }^{41}$, y otra de 1615.

Pese a que la muestra que aquí presentamos de la correspondencia entre la infanta y el marqués es poco relevante en número no lo es, sin embargo, en cuanto a su calidad, tal es el valor que su contenido aporta para conocer los puntos de vista de ambos sobre las circunstancias políticas y personales que les afectan. De cualquier forma esta veintena de misivas puede darnos siquiera una idea de la relación epistolar que ambos corresponsales mantuvieron durante cerca de diecisiete años. La importancia de esta correspondencia puede, sin embargo, contrastarse con la ya editada por Antonio Rodríguez Villa en

\footnotetext{
38 San Lorenzo de El Escorial, 8 de agosto de 1614, IVDJ, Envío 86, Caja 121, doc. 498.

39 BOUZA ÁlVAREZ, Fernando: Comunicación, conocimiento y memoria en la España de los siglos XVI y XVII, Salamanca, Seminario de Estudios Medievales y Renacentistas, 1999, pp. 73-74.

40 Puede seguirse la turbulenta fortuna de dicha colección documental en ANDRÉs, Gregorio de, «La dispersión de la valiosa colección bibliográfica y documental de la Casa de Altamira» Hispania (Madrid) XLVI (1986) pp. 587-635.

${ }^{41}$ LLANOS Y TORRIGLIA, Félix de: Isabel Clara Eugenia. La novia de Europa, Madrid, 1928. IVDJ, Envío 38, Caja 50, n 86-88. No sabemos en qué fundó el autor la identificación del destinatario, sin embargo no parece que tal fuera el marqués de Velada sino el de Ladrada, mayordomo mayor de la reina Ana.
}

Hispania, LXIV/2, núm. 217 (2004) 467-514 
$1906^{42}$, intercambiada entre la infanta y el duque de Lerma. Sin duda alguna ésta última resulta de mayor trascendencia tanto por la relevancia política de ambos corresponsales como por el destacado volumen de cartas recogido, sin embargo la que ofrecemos aquí permite, pese a su escaso número, confrontar un punto de vista diferente, una visión distinta de la corte y de la política, la opinión que la infanta hace llegar a uno de sus principales confidentes e interlocutores en Madrid - paradójicamente antagonista y rival cortesano del duque de Lerma-, sobre lo que acontece en su corte flamenca y en Europa. Doña Isabel manifiesta en su escritura una proximidad muy definida hacia su interlocutor de manera que las confesiones y opiniones emitidas son de una riqueza extraordinaria para analizar la situación política de la Europa del momento. No elude situaciones o circunstancias sensibles como, por ejemplo, cuando refiere la violencia con la que es tratada su sobrina, la reina Ana de Austria, por su marido, Luis XIII ${ }^{43}$ o al confesar su frustración ante la permanente negativa de su hermano a satisfacer sus peticiones de honrar al marqués ${ }^{44}$. La confianza es recíproca en el marqués - y aunque sus cartas son escasas en relación con las de la infanta - tampoco parece rehuir el abordar asuntos comprometedores como sus tensas relaciones con el duque de Lerma ${ }^{45}$, la delicada situación cortesana con el enfrentamiento abierto entre los miembros de la facción de los Sandovales ${ }^{46}$ o sus juicios de valor sobre la situación de gobierno de la Monarquía ${ }^{47}$. Las epístolas reflejan también el desahogo y la naturalidad con las que ambos corresponsales refieren sus preocupaciones y aspiraciones presentes y futuras, amparados por la confidencialidad y la comprensión que se dispensan mutuamente.

No existen notables diferencias de estilo entre las cartas que la infanta remite a Lerma y las que envía a Velada, y sólo se distinguen en cuanto a su contenido. La correspondencia con el duque, si tomamos como referencia el conjunto estudiado por Rodríguez Villa, se extiende entre 1599 y 1611, aunque incorpore otras cartas sin fechar, abarcando un período cronológico similar al

42 Vid. supra nota 7.

43 "Çyerto yo la tengo byen grande pues llega el negoçyo a abella querydo poner las manos su marydo. Esto sea para bos. Su cólera es ter[r]yble, como de tartamudo», carta de la infanta Isabel al marqués de Velada, Mariemont, 22 de julio de 1616, BL, Add. 28.698, fols. 218r-219v.

44 «Es arta lástima mýa que no pueda ablar claro con mi hermano como serýa menester y que al cabo de treçe años que le suplyco una cosa no la yçyese pero como os dygo quedo con mucha. esperança que desta bez sea de açer», Bruselas, 14 de septiembre de 1612, ibidem, fols. 185r-186v.

45 «[El duque de Lerma] est[á] muy diferente conmigo de lo que suele, y debe de aver sido la causa parezerle que soy amigo del confesor [Luis de Aliaga] y averme topado en su casa don Rodrigo tres o quatro vezes en el tiempo que andavan en porfía si avía de salir de aquí o no", borrador de carta del marqués de Velada a la infanta Isabel, [S.1.], 16 de julio de 1612, ibidem, fols. 179r-184v.

46 "An me dicho que la Condesa de Lemos y su hemano [Lerma] no están bien avenidos y que ella y su confesor hablan de yrse a Galiçia», ibidem, fols. 179r-184v.

47 «El Duque no da audiençias y así aunque S.M. las da cada día padezen los negoçios y ay poco despacho según diçen», ibidem, fols. 179r-184v. 
que pertenecen las epístolas intercambiadas con Velada. En aquel repertorio son varias las cartas conservadas por año en contraposición con el que aquí damos a conocer, y la secuencia temporal es indudablemente más completa. En el conjunto de cartas intercambiadas entre la infanta y el marqués existen notables carencias. Así, hay una de 1599, fechada el 10 de junio desde el puerto de Cadaqués - de la misma fecha y desde el mismo lugar escribió doña Isabel a Lerma- y no se ha localizado ninguna más hasta 1612, aunque sí existen copias de tres remitidas por Velada a la infanta en septiembre de 1600 , mayo de 1607 y enero de 1609 . Desde entonces desaparece todo rastro de las remitidas por el marqués a la infanta y tan sólo conservamos las que ésta envió desde 1612 hasta cinco días antes del óbito de Velada, acaecido en El Escorial. Al confrontar ambos conjuntos, y si exceptuamos la desproporción numérica de las cartas remitidas por la infanta a Velada en relación con las enviadas por doña Isabel a Lerma, puede comprobarse el estilo familiar y cercano que emplea la hermana de Felipe III al comunicarse con ambos corresponsales, la similitud de los temas abordados - política, entretenimientos, asuntos familiares, rumores cortesanos, etc - y la complicidad que se adivina en cada párrafo. La infanta tenía en Lerma a su principal interlocutor en la corte madrileña, el nexo de unión con el rey, y de quien dependía en última instancia la conformidad y aprobación de las políticas emprendidas en los Países Bajos por doña Isabel y el archiduque Alberto. El contrapunto a las informaciones del duque estaba en Velada que, pese a las apariencias, era uno de sus principales adversarios políticos y un confidente extremadamente valioso para la infanta que de esta forma recibía de distintos corresponsales informaciones precisas con las que poder negociar con Madrid en mejores condiciones.

Otro aspecto a destacar de estas cartas, y sin duda igualmente relevante, es el hecho de constituir un ejemplo notable dentro de la escritura privada femenina ${ }^{48}$. La correspondencia en las elites resultaba ser una práctica habitual aunque con notables diferencias de género disponiendo los varones de un ilimitado acceso a la escritura mientras las mujeres, bien por su incapacidad para leer y escribir, o bien por condicionamientos sociales o religiosos muy rígidos, impuestos en muchos casos por sus consortes, disponían de un margen de acción muy estrecho. La infanta Isabel, debido a su propia posición social, no padecía

48 Véanse al respecto REQUESENS, Estefanía de: Cartes intimes d'una dama catalana del segle XVI. Epistolari a la seva mare la comtessa de Palamós, Barcelona, 1987; BARBEITo CARneIRO, Isabel: Mujeres del Madrid Barroco. Voces testimoniales, Madrid, Dirección General de la Mujer de la Comunidad de Madrid, 1992; TORRES, Concepción: Ana de Jesús, cartas (1590-1621): religiosidad y vida cotidiana en la clausura femenina del Siglo de Oro, Salamanca, Universidad de Salamanca, 1995; GRAÑA CID, María del Mar: «Palabra escrita y experiencia femenina en el siglo XVI», en CASTILLO GómEZ, Antonio (comp.): Escribir y leer en el siglo de Cervantes, Barcelona, Gedisa, 1999, pp. 211-242; CASTILLO GÓMEZ, Antonio: «La pluma de Dios. María de Ágreda y la escritura autorizada», Via spiritus 6 (1999) pp. 103-119; y BITTENCOURT Hule, Águeda Bernardete: «Cartas femeninas em universo masculino", en SÁEZ y CaSTILlo GómEZ (eds.), op. cit., vol. I, pp. 261-274.

Hispania, LXIV/2, núm. 217 (2004) 467-514 
ningún tipo de imposición que controlara ni su capacidad, ni su libertad para establecer relaciones epistolares con quien considerase oportuno. Además su condición de gobernante le confería autoridad suficiente para desarrollar actividades que a buena parte del mundo femenino, incluso el nobiliario, le estaban vedadas. Es por ello, por lo que estas misivas, al margen de su valor documental, permiten valorar nuevos aspectos de las prácticas epistolares femeninas. Estas cartas muestran un matiz más de la amplia variedad de estilos con los que la infanta se comunicó en función de la calidad y condición de sus corresponsales.

La correspondencia era, pues, un elemento esencial de la comunicación, un referente sobre el cual se asentaba cualquier relación familiar, amistosa o política. Por ello las cartas se constituyeron en la práctica de escritura más habitual en la España del Siglo de Oro hasta el punto que solía escribirse hasta cuando no había nuevas que dar, simplemente por el hecho de dejar constancia de que continuaba la comunicación, así se lo recordaba la infanta Isabel a Lerma cuando le decía lo «mucho que güelgo de escribir siempre, pero mucho más quando puedo dar nuevas de acá» ${ }^{49}$. Este placer que buena parte de las elites sociales mostraría por la escritura a partir del siglo XVII - superada ya la época de la oralidad-, se convirtió en un rasgo esencial de la sociabilidad cortesana, permitiéndoles adentrarse en un nuevo tipo de relación con los miembros de su círculo íntimo y con los demás ${ }^{50}$. Hasta tal punto fue importante la correspondencia que la grandeza de muchos miembros de la nobleza no sólo se medía por sus conocimientos sino por el volumen y calidad de la correspondencia que eran capaces de mantener. Por esta virtud fueron reconocidos tanto el mencionado Juan de Zúñiga, cuyo archivo de papeles heredó Velada, como Juan de Silva conde de Portalegre, entre otros. Fue el género epistolar un elemento indispensable de la identidad nobiliaria, y cortesana en general, reflejándose en las cartas todo el ritual derivado del intercambio de favores sobre el que se asentaba el propio estamento, y siendo además símbolo evidente del valor de la honra y el crédito aristocrático ${ }^{51}$.

En las relaciones personales, por lo tanto, las cartas eran lugar para el intercambio de confidencias, favores y cortesías, pero también para los consejos, exhortaciones a la fidelidad y amistad y recomendaciones, por ello resultan de vital importancia para entender las circunstancias de las diferentes filiaciones cortesanas en un momento determinado. Repletas de fórmulas de cortesía, buenos deseos y preocupaciones de carácter familiar, avisos, etc, las epístolas reflejaban sólidas lealtades y dependencias políticas y también el temor a per-

${ }^{49}$ Bruselas, 7-X-1606, RodríGUEZ VILLA, op. cit., p. 152, carta 104.

so Resulta muy interesante el estudio sobre la significación de la escritura para los nobles franceses del siglo XVII que hizo DEWALD, Jonathan en el capítulo VI, «The Meanings of Writing», de su obra Aristocratic experience and the originis of modern culture: France, 1570-1715, Berkeley-Los Ángeles, University of California Press, 1993, pp. 174-203.

si CARDIM, op. cit., p. 431. 
der el contacto ${ }^{52}$, como parecía entenderlas el conde de Oropesa al escribir al marqués de Velada que sus cartas «me son en todo tiempo de particular alivio" ${ }^{53}$. Así, pues, las cartas fueron también símbolo de un especial reconocimiento entre corresponsales, hasta el punto de acompañarlas de regalos, que no hacían sino incrementar el valor de la relación de amistad ${ }^{54}$. El reconocimiento mutuo expresado en favores simbólicos como cortesías y regalos, tenía su continuidad lógica en los favores concretos, esto es, el patronazgo, que siempre formaría parte esencial del proceso de intercambio: favor a cambio de reconocimiento y favor a cambio de promesas de futuro, favor o continuidad en una estima recíprocass, todo ello basado en el honor, garantía máxima del mantenimiento de esas relaciones. Resulta evidente tras analizar el contenido de las cartas de la infanta al marqués que, pese a las limitaciones que imponía la distancia, doña Isabel continuó velando por los intereses de su antiguo mayordomo mayor y que éste correspondió a su patronazgo respaldando sus opiniones ante el Consejo de Estado, informándole de cuanto requería su inteligencia y enviándole a menudo presentes de su agrado.

A tenor de lo referido parece que la correspondencia privada es también un testimonio único, quizá el más relevante, para profundizar en la naturaleza y alcance de las relaciones de amistad. Si bien «la amistad tiene un tenue y ambiguo lugar en nuestra cultura, [pues] carece de convenciones, derechos o deberes claros», a finales del siglo XVI y principios del XVII, sin embargo, «era un tema ampliamente discutido y claramente entendido" ${ }^{56}$. Uno de los principales símbolos de la amistad era, sin duda alguna, el «intercambio de regalos» ${ }^{57}$, que representaba la obligación recíproca entre dos amigos de ofrecerse ayuda sin que en ningún caso «ninguno de ambos sepa si va a acabar como deudor o como acreedor». La amistad debía entenderse como una relación absolutamente libre aunque en cierto modo representara una obligación. Este ideal de amistad era para autores clásicos como Cicerón y Séneca o contemporáneos como An-

52 Es indudable que las cortesías, recurso recurrente en toda correspondencia, fortalecían los lazos de amistad y eran un complemento a las relaciones cara a cara. Para conocer en profundidad la naturaleza de las relaciones entre nobles -en especial la epistolar- y sus circunstancias véase NEUSCHEL, Kristen B.: World of Honour. Interpreting Noble Culture in Sixteenth-Century France, Ithaca y Londres, Cornell University Press, 1989, en especial el capítulo III, "The exchange of Favor: The Claim to Honor and the Meaning of Relationships», pp. 69-102.

53 Oropesa, 19 de septiembre de 1610, BZ, Altamira, Carpeta 194, doc. 117.

${ }_{54}$ Un ejemplo sobre el intercambio de regalos como recurso para mantener el contacto permanente entre dos cortes nos lo ofrece GARCíA GARCíA, Bernardo: «Bruselas y Madrid: Isabel Clara Eugenia y el duque de Lerma» en ThOMAS, Werner y Duerloo, Luc (eds.): Albert $\mathcal{E}$ Isabella. Essays, Bruselas, Royal Museum of Art and History, Brepols, 1998, pp. 67-77.

ss CARDIM, op. cit., p. 76.

56 Un interesante estudio sobre el concepto de la amistad en la Inglaterra isabelina y jacobina puede verse en WOOTTON, David: «Francis Bacon: vuestro flexible amigo», en EllioTT, John H. y BROCKLISS, Laurence (dirs.): El mundo de los validos, Madrid, Taurus, 1999, p. 266.

57 Ibidem, p. 269. 
tonio Moro y Francis Bacon, «en primer lugar y ante todo un pacto de ayuda mutua, una forma de clientelismo mutuo». De esta forma se entendía que la amistad establecía unas relaciones de dependencia «entre iguales que se convertían en desiguales, de modo que uno pudiera ser dependiente del otro y com.probar así su amistad, invertiéndose después la desigualdad de tal modo que el otrora beneficiario pudiera demostrar su gratitud imperecedera. Semejante amistad era una póliza de seguro mutua en la que ambas partes establecían un derecho, pero en momentos diferentes y bajo circunstancias muy distintas, de modo que cada uno, al demostrar su lealtad, no sólo reconocía una obligación, sino que además aprobaba un examen de carácter» ${ }^{58}$.

Los vínculos que sugieren las cartas intercambiadas entre la infanta Isabel y el marqués de Velada reflejan unas relaciones estrechas aunque dada la desigualdad social de ambos corresponsales resulta complicado incluirlas dentro del concepto de amistad, con la significación que actualmente le concedemos, más privada y sentimental59. No parece que la amistad antes del siglo XVIII se basara únicamente en las relaciones de clientelaje y que no hubiera ningún sentimiento íntimo más allá de esos intereses particulares ${ }^{60}$. Indudablemente en los siglos XVI y XVII , «la amistad es inseparable de la alianza, el clientelismo y el favoritismo, conceptos que para nosotros son antitéticos con el de amistad, puesto que la amistad se refiere a la vida privada, en tanto que la vida pública es ostensiblemente gobernada por los principios revolucionarios de la imparcialidad y la carrera abierta al talento» ${ }^{61}$. Esto no excluye otro tipo de relación más allá de los vínculos políticos cortesanos, aunque la amistad fuese concebida esencialmente como un intercambio de favores y un compromiso político ${ }^{62}$. Con este sentido, precisamente, podrían definirse los lazos que desde antiguo unieron al marqués con doña Isabel. Entre ambos hubo algo más que una mera relación de intereses políticos y la permanente intercesión de Isabel ante su

\footnotetext{
58 Ibidem, p. 270.

59 En este sentido se puede estar de acuerdo con lo expuesto por Ignacio Atienza, si bien cabría distinguir entre las dos principales acepciones que el término amigo recibía en la Alta Edad Moderna y que afectaba indistintamente a criados y vasallos o a familiares y aliados políticos muy próximos, aunque cuando se aplicaba a estos últimos tenía lógicamente otra significación más allá de la referencia al habitual contacto cortesano. Véase ATIENZA HeRnÁNDEZ, Ignacio: «Teoría y administracion de la casa, linaje, familia extensa, ciclo vital y aristocracia en Castilla (s. XVI-XIX)», en CHAcón Jiménez, Francisco, Hernández Franco, Juan y Peñafiel Ramón, Antonio (eds.): Familia, grupos sociales y mujer en España (s. XV-XIX), Murcia, Universidad de Murcia, 1991, pp. 13-47.

${ }^{60}$ DewALD, op. cit., p. 104. El autor recoge la tesis de Lawrence Stone y otros que afirmaban la superficialidad de la mayoría de las relaciones, al referirse al concepto de amistad para los siglos XVI y XVII.

61 WOOTTON, op. cit., p. 271

62 Sobre el concepto de amistad y sus complejidades en la Edad Moderna europea también se ocupó AYMARD, Maurice: «Amistad y convivencia social», ARIÈs y DUBY, op. cit., pp. 57-101.
} 
hermano Felipe III reividincando la justicia debida al marqués ${ }^{63}$, el intercambio constante de regalos y noticias y las preocupaciones familiares y de la salud, nos acercan a unas relaciones que trascendían la cortesía y familiaridad con las que ella trataba a su viejo servidor.

La demanda permanente de noticias de la corte española, tan añorada para la infanta, hace del contenido de las cartas conservadas un elocuente testimonio de los estrechos vínculos que mantuvieron doña Isabel y el archiduque Alberto, su marido, con los antiguos privados de su padre, Felipe II. Tras su marcha a Flandes resultó de vital importancia continuar manteniendo esos vínculos, pese a las dificultades que la distancia imponía, para no quedar aislados políticamente y conseguir mayor eco y apoyo para sus reivindicaciones. Para la infanta, por tanto, contar con corresponsales que, como Velada, tenían acceso diario y libre al rey y a su privado, que conocían e influían en la política de la Monarquía desde su asiento en el Consejo de Estado, no era sino una necesidad que, trocada astutamente en virtud, le permitía obtener noticias extraoficiales y beneficiarse de ellas.

Veamos a continuación cuáles fueron los vínculos sobre los que ambos corresponsales establecieron una alianza política definida y basada en una más que cortés relación personal.

\section{ORIGEN Y CONSOLIDACIÓN DE UNA COLABORACIÓN POLÍTICA A TRAVÉS DE LAS CARTAS}

Desde la designación del marqués de Velada como mayordomo mayor de Isabel Clara Eugenia, el mismo día en que se le nombraba igualmente del príncipe Felipe, en San Lorenzo, el 9 de agosto de 1587, fueron muy estrechas las relaciones políticas y personales establecidas entre ambos. Desgraciadamente son escasas las evidencias documentales de lo que debió resultar alianza provechosa puesto que la infanta se convirtió en la principal valedora del marqués en la corte ${ }^{64}$. Velada había regresado de nuevo a ella — tras más de una década de retiro en sus tierras- para hacerse cargo de las Casas de los dos únicos hijos del monarca que permanecían solteros y para ello había contado con el valioso apoyo de Cristóbal de Moura y de su propio hermano, Fernando de Toledo, gentilhombre de cámara del rey, que había alcanzado por entonces gran influencia sobre el mo-

\footnotetext{
63 Un ejemplo: «y también que acordéis a mi hermano lo que ha que le sirve el Marqués de Velada, para que se resuelva en hacelle merced, que por el cuidado con que sirve la tiene bien merecida», Nieuwpoort, 23 de abril de 1602, RoDRíGUEZ Villa, op. cit. p. 59, carta 42.

64 Pese a la importancia del personaje tanto por su peso político como por el hecho de haber sido una mujer gobernante en la Europa moderna, la infanta necesita de una biografía que permita ubicar su figura en su justo contexto y que desentrañe cuestiones hasta ahora oscuras como su trayectoria política y cortesana durante el reinado de su padre. Buena parte de los estudios dedicados a doña Isabel y al archiduque Alberto son tratados desde una visión crítica por THOMAS, vid. nota 11.

Hispania, LXIV/2, núm. 217 (2004) 467-514
} 
narca. La infanta fue desde entonces su principal respaldo cortesano, mucho más quizá que Moura, por la propia situación política que le concedían las circunstancias, de hecho era la heredera al trono en el hipotético caso de que su hermano falleciera. Por eso Felipe II la conservó a su lado hasta su muerte y por eso también gozó de un poder y de una influencia similares a los que tuvieron sus tías, la difunta princesa Juana y la emperatriz María. Indudablemente un reducido número de cortesanos se alinearon en torno a su Casa —encabezados por el marqués-, integrada en su mayoría por personal femenino ${ }^{65}$, con vistas a una posible sucesión. Velada pronto comprendió el valor de su alianza con la infanta, compromiso que daría generosos frutos, como la concesión de la encomienda de Manzanares de la Orden de Calatrava o la inclusión de su hija, Antonia de Toledo, entre sus damas de mayor confianza ${ }^{66}$.

Desafortunadamente desconocemos el alcance del compromiso político establecido entre la infanta y el marqués aunque sí sabemos que existió una estrecha colaboración que perduró hasta la muerte de este último. Velada lamentaría la ausencia de su aliado más fiel en la familia real pues con la llegada al trono de Felipe III el futuro duque de Lerma controló, prácticamente a su antojo, el gobierno y la corte a través de sus numerosos parientes y bechuras. Intentó Lerma por todos los medios alejar al marqués de la corte ofreciéndole el oficio de mayordomo mayor de la Casa de la infanta en Flandes, con la promesa de concederle a su regreso la Grandeza. Velada no cedió a las presiones del duque y prefirió sobrevivir con su permanente hostilidad. Bien sabía el marqués que su marcha hubiera supuesto su inmediato fin político y aunque la situación en la corte a partir de entonces no iba a resultar cómoda prefirió ignorar el ofrecimiento, habida cuenta que no se fiaba de las promesas de su rival, porque aún le quedaban asuntos por resolver tales como la importante resolución de un pleito por la posesión de unos mayorazgos en litigio, los casamientos de sus dos hijos y la obtención de la grandeza para su Casa.

65 Una "relaçión de los criados y criadas de S.S.A.A. y sus gajes», sin fechar, abunda en la composición de la Casa de la infanta: como dueñas de honor Ana de Mendoza, Sancha de Guzmán y María Manuel; como damas Juana Jacincourt (desde 1 de diciembre de 1570, que recibía 27.000 maravedíes), Ana Manrique, Luisa e Isabel Laso, Hipólita de Cardona, Juana Enríquez de Mendoza, María de Aragón, Juana Manrique, Mencía de la Cerda, Francisca Manrique, Mariana de Castro, María de Castro, Catalina de Córdoba, Luisa Manrique, Isabel Gonzaga, Mariana de Mendoza, Catalina Zapata, Catalina Estefanía «dama enana» y Beatriz de Mendoza; más personal femenino, que preferimos omitir, figuraba entre guardasmenores de damas, damas de retrete, mozas de cámara, mozas de retrete, enfermeras, lavanderas, costureras y conserveras, entre otras. Como mayordomo mayor figuraba entonces Pedro Laso de Castilla y Zúñiga asistido por los mayordomos Juan Enríquez, Rui López Dávalos y el conde de Uceda. Era caballerizo mayor Gonzalo Chacón. Se puede observar que muchos de los oficiales, como éste último, y criados son los mismos que los de la Casa de la reina Ana de Austria. BPUG, Favre, Vol. XXXVII, fols., 28r-33v.

$66 \mathrm{La}$ infanta lamentaba su pérdida cuando se embarcó en Barcelona: «y lo que yo quyero a Antoñyca, que la soledad que traygo della es tanta que no lo sabrýa deçyr», carta al marqués de Velada, Puerto de Cadaqués, 10 de junio de 1599, BPUG, Favre, Vol. XXXV, fols. 86r-87v. 
Los diecisiete años que transcurrieron entre la llegada de la infanta a Flandes para gobernar junto a su marido, el archiduque Alberto, aquellos estados y la muerte del marqués, en 1616, aparecen reflejados en la correspondencia aquí recogida y nos ofrecen una significativa información sobre las relaciones entre las cortes de Madrid y Bruselas. Las noticias, juicios y opiniones de ambos corresponsales, en especial los de la infanta, sobre las mudanzas cortesanas, la práctica de gobierno de Lerma, la situación política y militar europea, resultan de un indudable interés no sólo para conocer mejor la trascendencia de los vínculos creados entre la hija del difunto Felipe II y su antiguo mayordomo mayor, sino para acercarnos a las inquietudes políticas, familiares y artísticas de dos importantes referentes de las cortes de Felipe II y Felipe III. Las cartas son la mejor imagen de una coyuntura política de importantes repercusiones para ambos aunque a niveles diferentes. Permiten conocer la importancia de otros corresponsales vinculados a ambos protagonistas y de los que desgraciadamente se han conservado escasos testimonios documentales como Johanna Jacincourt $^{67}$, camarera mayor de la infanta, Rodrigo Niño de Guevara, mayordomo mayor del archiduque Alberto y futuro segundo conde de Añover e Îñigo de Cárdenas, embajador en Francia, entre otros.

A pesar de la orfandad política en la que quedó sumido Velada tras la marcha de la infanta - asistió impávido a la desgracia de sus antiguos colegas de gobierno, alguno amigo personal como Cristóbal de Moura- continuó manteniendo un contacto epistolar permanente con ella, enriquecido por el intercambio frecuente de relaciones de noticias de la corte, trazas de aposentos y jardines, libros, manuscritos, animales ${ }^{68}$ y otros objetos.

Como máximo responsable de la Casa de la infanta, el marqués de Velada quedó encargado personalmente de asegurar el envío de los objetos y enseres que no pudieron ser embarcados en Barcelona con destino a Flandes antes de su marcha. Así, en la relación que el guardajoyas Hernando de Rojas hace llegar a Velada a finales de septiembre de 1600 , se recoge lo que queda pendiente de remitir y lo que ya se ha enviado. Entre lo primero se mencionan varios «COfres viejos y cajas» y dos chovas "que andan alrededor de palaçio, que no fue posible tomarlas». De lo enviado se destacan gatos y chovas, para cuyo mantenimiento y gasto se destinaron 817 reales de ración y 300 de ayuda de costa ${ }^{69}$.

\footnotetext{
67 «Quien no myra más que a su gusto y no el cansançio que puedo dar con vuestras cartas no dexaría pasar ocasión sin escribir a VS a quien deseo le aya dado nuestro señor tan buenas feliçidades de Pascua y entrada en año como deseo", carta de Johanna Jacincourt al marqués de Velada, Bruselas, 4 de enero de 1603, IVDJ, Envío 86, Caja 121, doc. 500.

68 "Con el papagayo os abréys olgado", carta de la infanta Isabel al marqués de Velada, Mariemont, 23 de mayo de 1615, BL, Add. 28.698, fols. 199r.-200v.

69 En el memorial de lo enviado se mencionaban los siguientes objetos: «un escritorio grande $\mathrm{n}^{\circ} 56$ pesa 26 arrobas» y que lleva el carretero Miguel de Cuenca, «un maletón de quero de la madera de la cama que dio la Emperatriz $n^{\circ} 81$ pesa 6 arrobas», «un cofre», «una caja larga sin cubierta de ençerado que lleba la madera de una cama de S.A. que tiene allá S.A.»; "un cajón grande», 
En noviembre de 1600 escribía a Johanna Jacincourt, camarera mayor de la infanta, para informarle del cuidado con que había ordenado el envío de objetos y animales exóticos para doña Isabel, entre ellos, búcaros, chovas, gatos, monos y papagayos, y lamentaba la «mucha soledad [que] me ha dejado esto que e embiado a Laredo que no me queda nada acá cosa de Su Alteça» ${ }^{70}$.

El intercambio de regalos entre ambos corresponsales debió ser frecuente a tenor de lo que reflejan las cartas conservadas ${ }^{71}$. Desgraciadamente tan solo contamos con testimonios de los presentes recibidos por la infanta, no obstante tales evidencias aportan informaciones muy valiosas sobre los gustos de los dos. El contenido de la correspondencia permite conocer muchas de sus principales aficiones significándose entre ellas los libros y la arquitectura, inclinación ésta última también compartida por otro de sus principales corresponsales, el duque de Lerma ${ }^{72}$. De la primera hay ejemplos tan notables como la remisión que hace el marqués de la «relaçyón de una comedya», que desgraciadamente se perdió $^{73}$, y de otros manuscritos de diverso contenido ${ }^{74}$. Aunque sea el envío de

«una arquilla pequeña», etc. También a cargo de «Guílez» fueron enviadas «ocho chobas en sus jaulones, quatro gatos de algalia en sus quatro jaulas, un cofre encorado de pelo largo, otro cofre barreado de yerro, otro como éste barreado de yerro [y] un arca en que ba la comida de los gatos y chobas», BPUG, Favre, Vol. XXXV, fols. 101r.-106v.

70 « [...] si los búcaros llegaren quebrados V.S. tendrá la culpa que los puso, lo demás si se quebrare la tendré yo porque lo e hecho poner con todo el cuidado que e podido. Las chovas y gatos ha días que están en Laredo. Deseo que los hospeden bien los monos y papag[ay]os que allá están, y la parda, deseo que lleguen bien y presto. De los seis navíos que vinieron de allá se han buelto los 4 y no han quedado sino dos y el Vizealmirante con ellos. En estos e procurado que vaya y que Estevan de Ibarra scriva al Vizealmirante de parte de S.M. que lo lleve y sentirá mucho que las chovas y todo lo demás no llegase bien», carta del marqués de Velada a Johanna Jacincourt, El Pardo, 6 de noviembre de 1600, BZ, Altamira, Carpeta 195, doc. 75 . "La ropa y savandijas están en Laredo esperando quien lo lleve», carta del marqués a Jacincourt, El Pardo, 29 de noviembre de 1600, IVDJ, Envío 86, Caja 121, doc. 595. Sobre el consumo de exótica véase PIEPER, Renate: «Papagaien und Bezoarsteine. Gesandte als Vermittler von Exotica» en Hispania-Austria II. Die Epoche Philipps II. (1556-1598), EDELMAYER, Friedrich (ed.), Viena-Munich, 1999, pp. 215-224. También STOLS, Edith: "De triomf van de exotica of de bredere wereld in de Nederlanden van de aartshertogen», en THOMAS y DUERLOO, op. cit., pp. 291-299.

71 GARCÍA GARCía, Bernardo: «Los regalos de Isabel Clara Eugenia y la corte española. Intimidad, gusto y devoción» en Reales Sitios (Madrid) 143 (2000), pp. 16-27.

72 García García, Bernardo: «Bruselas y Madrid: Isabel Clara Eugenia y el duque de Lerma», en THOMAS y Duerloo, op. cit. , pp. 71-72.

73 Carta de la infanta Isabel al marqués de Velada, Bruselas, 10 de diciembre de 1614, BL, Add: 28.968 , fols. $193 \mathrm{r} .-194 \mathrm{v}$.

74 «A my hermano enbýo una relaçyón muy larga de todas las fyestas y lo que se a echo dende que byno asta que se fue. Pyenso os la mostrará y para que gustéys más della os embýo ese papel que emos reýdo aquý con él. No me deçýs por autor y sy le quysyéredes mostrar a my hermano acedle sacar de otra letra», carta de la infanta al marqués, Bruselas, 13.de enero de 1616, ibidem, fols. 202r.-204v. «La relaçyón de la jornada [de las Entregas] e olgado de ver. Es dyferente de la que embyó my hermano, que no pareçe se yço para otra cosa que loar al de Uçeda», Bruselas, 20 de abril de 1616, ibidem, fols. $212 \mathrm{r} .-214 \mathrm{v}$.

Hispania, LXIV/2, núm. 217.(2004) 467-514 
la segunda parte del Quijote con el que se entretuvo la infanta durante los Carnavales de 1616 el que más llame la atención:

«Os agradezco a don Quijote que a sydo todo my pasatyempo estas Carnestollendas y sy ubyera llegado más temprano quyçá ubyéramos sacado dél para alegrallas pero no faltará alguna ocasyón» 75 .

El profundo interés de la infanta por la arquitectura se entiende tanto por el entorno artístico que disfrutó en la corte madrileña, en vida de su padre Felipe $\mathrm{II}^{76}$, como por el especial empeño, desde su llegada a Flandes, para abordar la compleja empresa que conllevó restaurar y reacondicionar las residencias reales para sus nuevos huéspedes, el patrocinio de numerosas edificaciones religiosas, acorde con el espíritu de la Contrarreforma, y la reconstrucción de numerosas infraestructuras públicas destruidas o afectadas por la larga guerra en la que estaban sumidos los Países Bajos desde $1568^{77}$. Esta afición - bien parece que heredada de las enseñanzas recibidas de Juan de Herrera y Francisco de Mora - se deja ver frecuentemente en las cartas que intercambió con Velada, reputado trazador ${ }^{78}$, y con el propio Lerma, cuyas opiniones reclama en numerosas ocasiones. A ambos solicitará la infanta diseños sobre algunos aposentos de los Sitios Reales españoles, como las «trazas de Aranjuez» que pide al marqués ${ }^{79}$ acudiendo a su buena memoria y diligencia:

«muy byen byno el papel de los aposentos y aunque yo ymajynaba que se entraba al cuarto nuevo por donde me deçýs me pareçýa que la pyeça donde yo dormýa y la guardar[r]opa quedarýan muy oscuras y aora me lo pareçe [y] más abyendo quytado la ventana que caýa al Jardýn [de] Felype»80.

También pide al duque en muchas de sus epístolas que como «buen maestro» en estas cuestiones le traslade consejos y sugerencias. Incluso requiere directamente la opinión de Mora y trazas de su mano pues carece de arquitectos de

75 Bruselas, 6 de marzo de 1616, ibidem, fols. 205r.-208v.

76 JORDAN, Annemarie: «Mujeres mecenas de la Casa de Austria y la infanta Isabel Clara Eugenia», en El Arte en la Corte de los Archiduques Alberto de Austria e Isabel Clara Eugenia (1598-1633). Un Reino Imaginado, Madrid, 1999, pp. 118-137.

77 De las empresas arquitectónicas emprendidas por la infanta se han ocupado, entre otros, Charles van den Heuvel, Birgit Franke, Tine Meganck, Annemie de Vos y Philippe Bragard, todos ellos coordinados por JONGE, Krista de: «Building Policy and Urbanisation during the Reign of the Archdukes: the Court and its Architects», en THOMAS y DUERLOO (eds.), op. cit., pp. 191-219.

78 Véase «Obras que... hazer para entretenerse. La arquitectura en la cultura nobiliario-cortesana del Siglo de Oro: a propósito del marqués de Velada y Francisco de Mora» vid. nota 20.

79 Carta de la infanta Isabel al marqués de Velada, Mariemont, 18 de junio de 1612, BL, Add. 28.698 , fols. $177 \mathrm{r} .-179 \mathrm{v}$.

80 Carta de la infanta Isabel al marqués de Velada, Bruselas, 20 de abril de 1616, ibidem, fols, $212 \mathrm{r} .-214 \mathrm{v}$.

Hispania, LXIV/2, núm. 217 (2004) 467-514 
similar experiencia y maestría ${ }^{81}$. Aquellas trazas que entretenían su tiempo le traían a la memoria sus recuerdos de juventud y eran el mejor consuelo contra su añoranza:

«Para deçyros la verdad, byen desbaratado me a pareçydo el aposento de Aranjues, a lo menos yo no perdyera el cor[r]edor por nada que syenpre me acuerdo lo que me e olgado en él» ${ }^{82}$.

Indudablemente tales aficiones contribuían a relajar las confesiones y avisos que ambos se intercambiaban a través de las cartas. Al margen de las cuestiones políticas y familiares que siempre estaban presentes en una correspondencia entre dos personalidades de estado, también había lugar para el comentario de asuntos menos trascendentes y más placenteros, para la nostalgia, para la ironía e incluso para el humor.

En relación directa con la sustancia de las cartas está, evidentemente, el estilo empleado por ambos corresponsales y que, tras una lectura detenida, resulta franco y natural, no obstante, siempre dentro de las normas de cortesía que establecía el protocolo implícito en cualquier «conversación escrita» entre corresponsales de desigual condición. La infanta se dirige al marqués en tono cordial y amistoso, afectuoso, cercano, familiar incluso, recordando las maneras que procuraba con el duque de Lerma. Se asemeja por la proximidad de trato a los modos que emplean en su correspondencia particular Felipe IV y la condesa de Paredes ${ }^{83}$. La escritura de la infanta evidencia, además, una práctica cotidiana, diaria, pues las cartas son originales y carecen de tachaduras o enmiendas, lo que permite deducir que son el fiel reflejo de una «conversación escrita» flui$\mathrm{da}$, reposada y cálida pero determinada y firme, que sugiere una coordinada relación entre pensamiento y pluma.

En conclusión, puede afirmarse tras la lectura detenida de las cartas que a continuación transcribimos íntegramente, que la correspondencia fue un elemento esencial de la sociabilidad cortesana, que contribuyó al mantenimiento de las alianzas políticas y al intercambio de noticias, juicios y regalos, y que es una fuente documental de imprescindible consulta no solamente para el conocimiento de las relaciones políticas sino también para adentrarnos en los usos

\footnotetext{
81 «Hacedme placer de decir a [Francisco de] Mora que si tiene compuestas algunas trazas de las que le quedaron nos las envíe, porque no querría que se acabasen de caer algunas casas que tenemos aquí, que aunque no se puede hacer en ellas aora más que sustentallas, lo que se hubiere de hacer para esto querría que sirviese después, y no he querido que toquen a ellas por no tener el voto de Mora, que no hallo acá quien sepa la mytá que él; y si tuviéredes algún rato ocioso vedlas, que ya sé cuán buen maestro sóis, y en todo holgaré con vuestro voto», carta de la infanta al duque de Lerma, Bruselas, 17 de junio de 1600, RodRíGuEZ VILLA, op. cit., carta 12, p. 18.

82 Ibidem, Bruselas, 10 de mayo de 1616, fols., 214r.-216v.

83 PÉrez Villanueva, Joaquín: Felipe IV y Luisa Enríquez Manrique de Lara, Condesa de Paredes de Nava. Un epistolario inédito, Salamanca, Caja de Ahorros y Monte de Piedad de Salamanca, 1986.
} 
de la corte. La muestra que a continuación presentamos de la correspondencia epistolar intercambiada entre la infanta Isabel y el marqués de Velada ofrece nuevos matices sobre la personalidad de doña Isabel al tiempo que permite evocar aspectos desconocidos de la personalidad política de este veterano cortesano. Asimismo constituye, pese a la desigualdad de los corresponsales, un miembro de la familia real y un noble, un testimonio único de la relevancia historiográfica alcanzada por el género epistolar, una valiosa muestra de esa suerte de «escrituras privadas» que fueron las cartas en el Siglo de Oro ${ }^{84}$.

${ }^{84}$ BOUZa Álvarez, Corre manuscrito, p. 138.

Hispania, LXIV/2, núm. 217 (2004) 467-514 


\section{CARTAS}

\section{NOTA A LA TRANSCRIPCIÓN:}

Se ha considerado oportuno incorporar a cada carta, precediendo a su transcripción, un breve compendio de su contenido, destacando las cuestiones abordadas de mayor relevancia. En lo relativo a las misivas de la infanta se ha conservado su ortografía original caracterizada por la constante utilización de la letra $y$ en lugar de la $i$; asimismo y para facilitar la lectura del texto se han adoptado criterios ortográficos actuales. El estado de conservación de determinadas cartas ha impedido la correcta lectura de algunos fragmentos del texto original. Cuando ha sido posible, sin aventurar demasiado, se ha procedido a su reconstrucción. Sin embargo en los casos en los que la escritura se ha perdido por la desaparición material del papel o por el efecto de las tintas transparentadas se ha decidido dejar el lugar en blanco con la abreviatura non legitur (n.l.). Por lo que respecta a las menciones personales, geográficas o institucionales, todas han sido identificadas de forma breve en la notación a pie de página, refiriendo en el caso de los personajes citados su situación en la fecha de la carta en la que figuran a excepción de aquéllos más cercanos a ambos corresponsales en los que se ha optado por ampliar la información. Para concluir consideramos oportuno, evitando así confusiones innecesarias, advertir que las menciones a «mi primo» y «mi hermano» por parte de la infanta se refieren a su marido el archiduque Alberto y al rey Felipe III respectivamente.

I.- Carta de la Infanta Isabel al Marqués de Velada, Puerto de Cadaqués, 10 de junio de 1599, BPUG, Favre, Vol. XXXV, fols. 86r.-87v.

La infanta se despide desde su embarque en la costa catalana antes de partir para Flandes. Recuerda al marqués sus gestiones ante su hermano Felipe III con el fin de obtener de él la promesa de la concesión de la grandeza.

Marqués, mucho e olgado con vuestra carta y creo muy byen todo lo que me deçýs en ella por tener probado de la manera que me abéys serbydo syempre de que yo estoy tan agradeçyda como es raçón, y no syento syno no tener muchas ocasyones para mostraros esto, y lo que yo quyero a Antoñica ${ }^{85}$, que la soledad que traygo della es tanta que no lo sabrýa deçyr.

85 Antonia de Toledo y Colonna, hija del marqués de Velada y su segunda esposa Ana de Toledo y Colonna, nacida a mediados de la década de 1580, fue dama de la infanta Isabel desde 1596, AGP, Caja 278, Exp. 5. A partir de septiembre de 1598 desempeñó igual oficio en la Casa de la reina Margarita. En 1606 se casó con Juan Luis de la Cerda y Aragón duque de Medinaceli- para éste su segundo y último matrimonio- dándole un heredero varón Antonio Luis de la Cerda, futuro VIII Duque. 
Vos no dexéys de escrybyrme cuando ubyere ocasyón por lo que olgaré syempre de saber muy buenas nuebas vuestras. A my hermano ${ }^{86}$ suplyqué en las postreras palabras que le ablé que acabase de açeros la merçed que le tenýa pedydo. Respondyóme que bastaba mandárselo yo y asý aguardaba las prymeras cartas con alboroço para saber que estubyese echo pero no me pareçe que lo está pues no me deçýs nada y asý os pydo que me abyséys qué dylygençya se podrá açer para que se acabe, que yo deseo tanto que esto sea antes de salyr de España que me güelgo de lo que nos deternemos en este puerto por que me lo podrá abysar.

Estamos más despaçyo de lo que se pensó por un lebeche muy reçyo que se nos lebantó esta noche que suele durar algunos dýas pero estamos muy byen y con tan lynda bysta de tyerra que es entretenymyento que las vysitas que andan de una galera en otra. Emos tenydo muy solene mysa y proçesyón que pareçe no quyso nuestro señor que dexásemos de oýlla este dýa. Yo no la andube sino por my prymo ${ }^{87}$ por ser las calles de manera que para subyr a la yglesya fue menester syllas. Quedámonos en ella la Archiduquesa ${ }^{88}$ y yo mientras andaba la proçesyón y pues ubo enbaxador y nunçyo ${ }^{89}$ y banco de grandes [n.l.]. Se han pasado byen estos dýas syno fue la prymera noche que todos nos mareamos. Estamos regaladísimos de Juan Andrea ${ }^{90}$ y muy serqano no pone en otra cosa el cuydado syno en lo que me toca y que yo lo esté byen me puede pagar my hermano la soledad que traygo suya, que es mucha. De don Her-

\footnotetext{
${ }^{86}$ Felipe III (1578-1621).

87 El archiduque Alberto de Austria era el décimo hijo del emperador Maximiliano II y de la infanta María y aunque nacido en la ciudad austriaca de Wiener Neustadt en 1559 se educó en la corte española de su tío Felipe II a donde llegó en 1570 junto a sus hermanos el archiduque Wenceslao y la ya reina Ana. Se convirtió en el sobrino favorito del rey hasta el punto de ser considerado en determinados momentos firme candidato a sucederle en caso de fallecer sin heredero varón. Felipe II consiguió para él el cardenalato en 1577. Tras la conquista de Portugal en 1581 Felipe II concede a Alberto el rico priorato de Crato y en 1583 le designa virrey e inquisidor general del reino luso. En 1593 vuelve a Madrid, llamado por el rey, para formar parte de la Junta Grande, especie de consejo de regencia establecido para la formación política del príncipe Felipe como futuro monarca. $\mathrm{Al}$ año siguiente Clemente VIII le nombra arzobispo de Toledo. Tras la muerte de su hermano Ernesto, se hizo cargo del gobierno de los Países Bajos en 1595. En 1598 se anuncia su compromiso matrimonial con la infanta Isabel Clara Eugenia, previa renuncia a su dignidad y a todo beneficio eclesiástico, al tiempo que ambos son designados como soberanos de los Países Bajos bajo tutela de la Monarquía Católica. Falleció sin descendencia en el palacio de Coudenberg el 13 de julio de 1621 a los sesenta y un años de edad, El Arte en la Corte de los Archiduques, pp. 310-317. Una completa semblanza del archiduque la recoge BENTIVOGLIO, Guido: Relaciones, Madrid, María de Quiñones, 1638, RB, IV/1771, h. 49-51. También MARTíneZ Millán, José: «El archiduque Alberto en la corte de Felipe II (1570-1580)», en THOMAS AND DUERLOO (eds.), op. cit., pp. 27-37.

${ }^{88}$ María de Baviera, archiduquesa de Austria, esposa del archiduque Carlos de Estiria y madre de la reina Margarita.

${ }^{89}$ Camilo Caetani, Patriarca de Alejandría.

90 Giovanni Andrea II Doria (1540-1606), capitán general de la mar desde 1583 y consejero de Estado desde 1594 (confirmado en su plaza por Felipe III en 1599). En 1602 recibió el marquesado de Finale.
}

Hispania, LXIV/2, núm. 217 (2004) 467-514 
nando [de Toledo] ${ }^{91}$ deseo saber cómo le ba. Que Dios os guarde como deseáys, de la galera, en el puerto de Cadaqués, a 10 de junio. Isabel.

II. Copia de carta del Marqués de Velada a la Infanta Isabel, San Lorenzo, 26 de septiembre de 1600, BZ, Altamira, Carpeta 195, doc. 72 [duplicado doc. 73 ].

Noticia sobre las actividades cinegéticas de los monarcas. Felipe III prepara su jornada a varias ciudades castellanas que visitará por primera vez como rey con el fin de asegurarse su voto favorable para el servicio de millones. Avisos de corte. Remisión de varias chovas.

A 14 deste escriví a V. A. y otra carta a 18, ambas llevó un correo que despachó don Juan Carrillo ${ }^{92}$ y anoche muy tarde supe que partía otro con despachos de S. M. y como a poco que escriva a V. A. no havrá mucho que deçir en esta.

S. M. queda bueno gracias a Dios y partió de Madrid para San Lorenço93 a 18 deste. Vino a comer a la Torre ${ }^{94}$ y a dormir aquí donde ha muerto hartos venados y con [e]sto pasa muy bien el tiempo. Desde ayer acá haçe frío aunque no llueve.

El Cardenal de Toledo 95 a ydo a Valladolid para venir con la Reyna ${ }^{96}$ nuestra señora que creo llegará al Bosque de Segovia ${ }^{97}$ a 4 o çinco del que viene y allí saldrá S. M. y se bendrán luego juntos aquí donde diçen que pararán hasta Todos [los] Santos y pasarán al $\mathrm{Pardo}^{98}$ a las palomas y que de allí yrán a Buitrago ${ }^{99}$ que lo tiene muy prevenido el duque del Infantazgo y andarán allí a caça algún día y pasarán a Burgos y de allí dizen en que a León y Toro y Çamora y que no se entrará en Madrid o se para[rá] poco en él. Pienso que si la Reyna nuestra señora viene en ello, que traerán aquí las damas de Madrid.

${ }^{91}$ Fernando de Toledo Dávila, segundo hermano del marqués de Velada, gentilhombre de cámara de Felipe III y comendador de la Zarza y Peñafiel de la Orden de Alcántara. Murió en Valladolid en el verano de 1602.

92 Servidor de la emperatriz María.

93 Real Sitio y Monasterio del San Lorenzo el Real de El Escorial.

94 Torrelodones (Madrid)

95 Cardenal arzobispo de Toledo Bernardo de Sandoval y Rojas, tío del duque de Lerma, promovido desde la diócesis de Jaén a la archidiócesis primada de Toledo en 1599, a la muerte de García de Loaysa Girón.

96 Margarita de Austria (+1611), hija de los archiduques Carlos de Estiria y María de Baviera.

${ }^{97}$ El Real Sitio de Valsaín, en Segovia, era también conocido como El Bosque, uno de los principales cazaderos de los monarcas que solían frecuentar, junto con El Pardo, en el otoño.

98 Real Sitio de El Pardo, por su cercanía a la villa de Madrid, fue uno de los lugares preferidos por el rey y su familia para la montería y otras distracciones.

99 Buitrago de Lozoya, villa perteneciente al duque del Infantado, entonces Íñigo López de Mendoza (1536-1601), quinto titular de la Casa ducal. 
La mayor parte de las çiudades han venido ya en el serviçio que de más de lo que esto ymporta para S. M., porque aya más comodidad para acudir a las cosas de allá, e holgado mucho dello.

A fray Pedro Manrique, hermano de la condesa de Puñoenrrostro ${ }^{100}$ ha dado S.M. el Obispado de Tortosa ${ }^{101}$.

El arçobispo de Sevilla ${ }^{102}$ y el obispo de Quenca ${ }^{103}$ dizen que son muertos.

Las chovas y gatos y el chovo con ellos son ya partidos y yo quedo muy enojado con el chovo porque se fue sin dos chovas que handan bolando por Madrid y diçen que no las pudo tomar.

Si yo me hallara allí quando partió no se fuera sin ellas. Háçense diligencias por tomarlas y en tomándolas las llevarán en una jaula al puerto, que temo se han de detener allí los navíos más de lo que yo querría. Esto es todo lo que de acá ay aora que poder deçir a V. A.

A tiempo que me dizen que parte el correo y si no tuviere tiempo para scrivir a su primo de $\mathrm{V}$. A. supplico a V. A. me disculpe pues puede tener ésta por suya, Dios guarde la sereníssima persona de V. A. como deseo, de San Lorenço el Real, en 26 de septiembre 1600.

III. Copia de capítulo de carta del Marqués de Velada, mi señor, para la serenísima Infanta doña Ysabel becha a 17 de mayo (de) 1607, BL, Add. 28.698, fols. 175 r.-176r.

Interesante discurso sobre la conveniencia de uná suspensión de armas en Flandes. El marqués expresa abiertamente su juicio sobre las negociaciones con las Provincias Unidas y las ventajas e inconvenientes derivados de la asunción de una paz o de una tregua.

Acá estavan muy contentos con los avisos que vinieron por vía de mercaderes de la suspensión de Armas con las Yslas ${ }^{104}$, entiendo que eran por mar y tierra. Después que an venido los despachos de S. A. se a sentido mucho que

${ }^{100}$ Ana Manrique (+1616), esposa de Francisco Arias Dávila y Bobadilla, conde de Puñonrostro $(+1610)$.

101 «A fray Pedro Manrique de la orden de San Agustín han proveído del obispado de Tortosa que vale 14.000 ducados de renta", De Madrid 23 de setiembre 1600, CABRERA DE CÓRDOBA, Luis: Relaciones de las cosas sucedidas en la cortes de España desde 1599 basta 1614, prólogo de Ricardo García Cárcel, Salamanca, Junta de Castilla y León, 1997, p. 84.

102 Rodrigo de Castro. «El cardenal de Sevilla estuvo a los 9 y 10 de este mes tan apretado de la orina con cierta pedrezuela que se le atravesó en la vía, que le tuvieron aquí por muerto; pero tuvo fuerza para echarla y libróse, aunque su mayor enfermedad son más de ochenta años de edad", De Madrid, 27 de mayo 1600, ibidem, p. 70.

103 «Murió el obispo de Cuenca don Pedro Puertocarrero, que era del Consejo de Estado, y fue Inquisidor Mayor, el miércoles pasado en su iglesia», De Madrid 23 de setiembre 1600, ibidem., p. 84.

104 Provincias Unidas llamadas comunmente Holanda. Actuales Países Bajos. 
sea sólo por tierra, pues por allí es por donde las Armas de S. M. y las de S. A.. pueden haçer daño a los enemigos y por Mar son ellos los que nos le pueden haçer muy grande hallándose con tantos navíos, marineros, artillería y muniçiones y nosotros sin el rrecaudo ques neçesario para esto, y es menester tiempo para prevenirle; y los enemigos emplearán en la Mar todo el gasto que escusaren de la guerra de tierra por la suspensión y el tener paz y guerra juntamente con una misma provinçia y gente también a pareçido cosa muy extraordinaria. Yo tengo por sin duda que allá se tiene por çierto o muy gran esperança de que llegados los poderes de S. M. la suspensión será por mar y tierra, y esto es lo que acá se entiende que conviene a S. M. y a V. V. A. A.. Temo mucho que algunos del país no ayan dicho que aunque la suspensión sea en esta forma que $V$. V. A. A. quedarán con paz por la parte de sus estados y con el comerçio en ellos, y sin el gasto de la guerra sacando los estranxeros del país lo qual las vezes que se a provado se ha visto lo que se a perdido y que no a sido medio para consiguir la quietud. Y pienso que se puede fiar poco de la intençión de los questo dixeren pues se puede temer que por este camino se quieran hazer libres y rrepública. Y que para esto se conçierten entre sí los países obedientes con los reveldes viendo la gente de guerra fuera de los estados. Y así es neçesario mirarlo todo mucho y para que aya tiempo para esto lo mejor de todo sería haçer una suspensión larga general en todas partes por Mar y tierra con el comerçio destos Reynos para que aviendo provado la ganançia y quietud y çesado las contribuçiones que haçen se siguiese una paz muy firme que venga a estar muy bien a todos. Y en quanto durare la suspensión se podrán ganar las caveças de la guerra y los que son interesados en ella para que también deseen y procuren la paz.

Esto, suplico a V. A., sea sólo para V. V. A. A., quel çelo, amor y deseo que tengo de servir a V. V. A. A. me a obligado a deçir todo esto, suplicándoles me perdonen el averme metido en ello.

S. M. manda que vaya allá don Diego de Ibarra ${ }^{105}$ para tratar de estas cosas, el qual partirá con mucha brevedad. Plegue a Dios que la suspensión se haga general como espero para que allá y acá pueda aver más quietud y es lo que nayde la de[sea] más a V. V. A. A. que yo.

IV. Copia del capítulo de carta de S.A. para el Marqués de Velada fecha en Bruselas a 20 de enero 1609, BPUG, Favre, Vol. XXXVII, fols. 159r.-160v.

Obvian comentarios. Sobre la pretensión del marqués de ser honrado por el rey con la grandeza.

105 Miembro de la poderosa familia vasca de los Ibarra, bien asentados en la corte y la administración, Diego de Ibarra era consejero de Hacienda desde 1596 y miembro del Consejo de Guerra desde 1600. En 1603 ocupó plaza en la Contaduría Mayor de Cuentas. Falleció en 1610. 
A mi hermano escrivo sobre vuestro negoçio respondiéndome a lo que escrivió aora que es esto:

Prometo a V.A. que tengo buena voluntad al Marqués de Velada, y que deseo hazerle merçed, y ando mirando en todo porque ay otros que no les falta que alegar para esta misma pretensión, y el [Duque] de Lerma ${ }^{106}$ me dize: yo soy de los que más desean el bien y acresentamiento del Marqués de Velada porque le e visto servir muy bien siempre al Rey, por ser él tan honrrado cavallero y amigo mío. Ningún negoçio particular tray (g) a ara tan a mi cargo como los suyos, deseándoles todo buen suçeso. Plegue a Dios que assí le tenga que no se en que se pueda rreparar ni haçer consequençia.

V. Carta de la Infanta al Marqués de Velada, Mariemont, 18 de junio de 1612, BL, Add. 28698, fols. 177r.- 179v.

La infanta manifiesta su alivio al ser finalmente rechazada la candidatura del archiduque Alberto para suceder a su hermano fallecido, Rodolfo II. Desde el bando protestante, el príncipe Christian Alhalt-Bernburg, gobernador del Alto Palatinado, había maquinado para que la elección imperial, habida cuenta del enfrentamiento que existía entre Rodolfo y su hermano Matías, recayera en $\mathrm{Al}$ berto, siendo el elector palatino, como el príncipe de más edad, el que dirigiera finalmente los asuntos imperiales ${ }^{107}$. La elección imperial de Matías no fue contestada. Agradecimiento por el envío de unas trazas del Real Sitio de Aranjuez y mención del estado de su «negocio».

Marqués, an ydo con tanta prysa todos los correos estos dýas que no e podydo açer esto y aunque éste baya con la mysma para llebar la nueba del nuevo Emperador [Matías] de que yo no acabo de dar graçyas a nuestro señor que nos aya lybrado deste trançe que asý quyero llamar al que emos pasado todos estos dýas con lo que porfyaban los eletores en my prymo.

No quyero dexar de escrybyros estos rynglones para deçyros como e reçybydo todas vuestras cartas y las traças de Aranjuez ${ }^{108}$. Por la postrera e bysto en la determynaçyón que estábades a que no os déys prisa asta que tengáys

106 Francisco Gómez de Sandoval y Rojas V marqués de Denia y I duque de Lerma ( desde 1599). Valido de Felipe III, consejero de Estado, sumiller de corps y caballerizo mayor del rey. Para todo lo concerniente a su biografía remitimos a la obra imprescindible de Feros CARRASCO, Antonio: El Duque de Lerma. Realeza y privanza en la España de Felipe III, Madrid, Marcial Pons, 2002, $1^{\text {a }}$ edición en castellano de la original Kingship and Friendship in the Spain of Philip III, 1598-1621, Cambridge University Press, 2000.

107 Sobre el contexto político y militar europeo recomendamos la edición revisada y ampliada de PARker, Geoffrey (ed.): The Thirty Years 'War, Londres y Nueva York, Routledge, 1997, p. 30. Esta versión es posterior a la española de la editorial Crítica de 1988.

${ }_{108}$ Real Sitio de Aranjuez, uno de los lugares predilectos de Felipe II, a donde solía trasladarse el rey con su familia durante la primavera.

Hispania, LXIV/2, núm. 217 (2004) 467-514 
otra mýa por que pyenso que boy sacando de rastro en lo que topa vuestro negoçyo y en aclarando os lo abysaré y entretanto no dexo de açer todas mys dylygençyas para que salgamos con él. Plega a Dyos que sea como yo os deseo y que os guarde.

Que no tengo lugar para más, otras dyrán la llegada de don Rodrygo ${ }^{109}$ y su reçybymyento. Muestra ser muy buestro amygo. De. Marymont, a 18 de junyo [de] 1612. Isabel.

VI. Borrador de carta del Marqués de Velada a la Infanta Isabel [ incluye anotaciones marginales autógrafas del remitente], [S.l.], 16 de julio de 1612, BL, Add. 28.698, fols. 179r.-184v.

Satisfacción por la pacífica elección imperial de Matías y la finalmente frustrada del archiduque Alberto. Noticias relativas a la llegada del duque de Mayenne a España para tratar los casamientos con Francia. Convocatoria de la Junta de Portugal para analizar la posibilidad de que el príncipe sea jurado por el reino sin necesidad de acudir allí. Contento del duque de Lerma por el buen trato dispensado a Rodrigo Calderón a su llegada a Flandes. Desconfianza hacia este último. El marqués confiesa su temor a que la amistad que mantiene con el confesor del rey, fray Luis de Aliaga, sea la causa de la hostilidad que le muestra el duque. Desconsuelo ante la posibilidad de que otros sean honrados antes que él. Noticias de la corte. Complacencia por la elección del conde de Añover como nuevo mayordomo mayor de los archiduques.

A $1^{\circ}$ deste reçibí la carta que $V$. A. me hiço merçed de escrivirme a 18 del pasado y quiero començar ésta con dar a V. A. dos norabuenas, la primera de averse librado de lo que V. A. tanto temía en la elecçión del Emperador y la otra de que ésta se aya hecho en quién salió y con tanta quietud. Plegue a Dios sea para tanto serviçio suyo como la Christiandad a menester.

Graçias a Dios que V. V. A. A. estavan buenos que esto mismo nos an confirmado las cartas que an venido de aý de 24 del pasado.

S. M. y todos sus hijos tienen salud si no es la señor ynfanta doña Margari$\mathrm{ta}^{110}$ que tiene un poco de calentura y unas camarillas. Y esta semana pasada se

109 Rodrigo Calderón, I conde de la Oliva, principal favorito del duque de Lerma. Tras el óbito de la reina Margarita en el otoño de 1611 se vio implicado en un proceso judicial en el que se le acusaba directamente de haber inducido la muerte de la soberana, de quien era secretario, alegándose la manifiesta hostilidad de aquélla hacia su persona. Consiguió Lerma de Felipe III el perdón, a falta de pruebas sólidas, con la condición expresa de abandonar la corte. Fue enviado en 1612 como embajador extraordinario a Bruselas para negociar con los archiduques la reforma militar del ejército de los Países Bajos y continuar los contactos secretos con algunos líderes de las Provincias Unidas. A su regreso fue recompensado con el título de marqués de Sieteiglesias, García García, Bernardo: La Pax Hispanica. Política' exterior del Duque de Lerma, Lovaina, Leuven University Press, 1996, p. 73.

${ }^{110}$ Infanta doña Margarita Francisca, nacida el 24 de mayo de 1610. 
esperava al Duque de Umena ${ }^{111}$ y a se savido que le dio una calentura en Buytrago a donde embió $\mathrm{S}$. M. al doctor $\mathrm{Medrano}^{112}$, su médico de cámara, y un médico de familia. En llegando aquí pienso que se darán priesa a despacharle y diçen quel Rey y el Prínçipe nuestro señor ${ }^{113}$ y sus dos hermanos ${ }^{114}$ pasarán a Castilla y ni el tiempo es bueno para caminar ni en él suele estar muy sano Valladolid. También se a començado a deçir que an de yr a Portugal, no sé lo que será. Aquí a días que se haze una junta de los que vinieron de Portugal sobre las cosas de aquel Reyno ${ }^{115}$. Házese en cảsa del confesor ${ }^{116}$, y de los de acá entran en ella él y don Juan de Ydiáquez ${ }^{117}$ y Hernando de Matos ${ }^{118}$.

Contentísimo tienen V. V. A. A. al Duque de Lerma con lo que allá se a hecho con don Rodrigo [Calderón]. Él a hablado siempre bien en mí y dicho que me haze toda la amistad que puede. Algunos ratos lo e creydo y otros no. Siempre que le e hablado en mi negoçio me a respondido las muchas causas y raçones que ay para que se haga y ques mui mal hecho no hazerlo. Aora a la postre no sólo pienso que no me a ayudado pero que también a hecho que su amo [el Duque de Lerma] esté muy diferente conmigo de lo que suele, y debe aver sido la caussa parezerles que soy amigo del confesor [fray Luis de Aliaga] y averme topado en su casa don Rodrigo tres o quatro vezes en el tiempo que andavan en porfía si avía de salir de aquí o no. Y tengo por sin duda que ésta a sido la causa prinçipal para que no se hiçiese conmigo aora lo que se hiço con otro y muéveme a creerlo assí que estas últimas vezes que e hablado al Duque aviéndome dicho otras muchas que se haría y señaládome plaço para ello y dí-

111 Henri de Lorraine, duc de Mayenne (1578-1621), embajador extraordinario de Luis 'XIII para tratar los casamientos entre éste y la infanta doña Ana y el príncipe don Felipe, futuro Felipe IV, y la princesa Isabel de Borbón, hermana del rey galo.

112 Catedrático de medicina de Salamanca, Medrano, ocupó la plaza de médico de cámara del rey tras la muerte de su anterior titular el célebre doctor Mercado en 1611.

113 Felipe IV (1605-1665).

114 Infantes don Carlos (1607-1632) y don Fernando (1609-1641), éste último más conocido como cardenal-infante.

115 «Hácese una junta en casa del confesor de S.M., donde entran don Cristóbal de Mora, y el conde de Sabugal, merino mayor, y el licenciado Mendo de Mora, y Manuel de Vasconcellos y el secretario Hernando de Matos, todos portugueses, y de don Juan de Idiáquez, para ver la forma que podrá haber para jurar en Portugal al Príncipe, sin que vaya S.M. allá ni él, y que asímesmo no se puedan jurar los privilegios y libertades de aquel reino, y tratar de camino como sirvan a S.M. con los 500.000 ducados que han ofrecido para la jornada, porque se hallan muchos inconvenientes para haberla de hacer», De Madrid, a 7 de Abril de 1612, CABRERA DE CÓRDOBA, op. cit., p. 470.

${ }^{116}$ Fray Luis de Aliaga, de la Orden de Santo Domingo, confesor de Felipe III y consejero de Estado desde 1608.

117 Juan de Idiáquez, miembro de mayor antigüedad en el Consejo de Estado, fue hasta su muerte aliado y estrecho colaborador político del duque de Lerma.

118 " Han proveído cuatro secretarios para la negociación que tenía Pedro Álvarez Pereira, secretario de Portugal [...] el otro se llama Fernando de Matos, canónigo de Lisboa, para lo Eclesiástico y Órdenes», De Valladolid, 15 de junio de 1602, CABRERA DE CÓRDOBA, op. cit., pp. 145-146.

Hispania, LXIV/2, núm. 217 (2004) 467-514 
chome quel Marqués de Poça ${ }^{119}$ con quien él tenía obligaçión de cumplir era muerto y que todos los demás no podían hazer consequençia conmigo. Aora, últimamente, me a dicho que era aý el Marqués de Villanueva del Fresno ${ }^{120}$ y el Conde de Olivares ${ }^{121}$ y otros que se sintirían mucho que se hiçiese esto conmigo y que no todos los Ayos se avían cubierto. Así me habló muy despegadamente y muy diferente que otras vezes y quexándose del travaxo que tenía aý de lo que le cansavan y con aver sido esto en la saçón que fue, tengo por más caussa para pensar lo que arriva digo de la amistad del confesor, el qual es bonísimo hombre, y muy recto y muy útil para S. M. y que a pasado y sufrido muchos travaxos en obras y en palabras, y él puede deçir con verdad que siempre le e pedido que no hable a S. M. en mí. A tenido y tiene mucha gana de recogerse a su çelda y aunque su hermano de V. A. está muy bien con él, pienso que a de venir a parar en esto en lo que topa aora my negoçio. Pienso que es lo que aquí he dicho.

Lo de atrás puede aver sido quel de Uzeda ${ }^{122}$ no a estado bien en ello según me an dicho. No sé si es verdad y él muestra que es muy mi amigo.

También me dizen que S. M. lo a querido y que se lo an estorvado, aunque otras vezes me ayan ayudado. Yo no e hablado palabra a S. M. ni al Duque después que pasó lo de aora. Dízenme que a ofreçido el Duque a su hermana la [Condesa] de Altamira ${ }^{123}$ que quando saquen al Prínçipe nuestro señor a que le sirvan hombres mandarán cubrir al Conde de Altamira ${ }^{124}$, y la Condesa a hecho que el confesor de las azafatas del Prínçipe nuestro señor y de su hermana ${ }^{125}$ les pida a ambos hermanos que hablen al Rey y al Duque muy apretadamente que manden cubrir al de Altamira, y así le hablaron y su nuera de V. A., que sabe mucho, preguntó a su açafata que quien se lo avía pedido que si avía sido su Aya. Respondióle que no y apretóle más y húvole de deçir que su confesor respondióle que lo haría, y así habló al Duque muy apretadamente. Él le respondió que estava yo aquí, con quien no se avía hecho, y ella le respondió, pues hágase con entrambos. De manera que si se hiçiese conmigo será por la consequencia para el Conde de Altamira mas no por mí ni mis serviçios, y el no averme honrrado a mí hasta aora dan por excusa la quexa que tendrían otros, y

119 Francisco de Rojas, III marqués de Poza, Presidente del Consejo de Hacienda (1595-1602). Desde su cese como responsable de Hacienda ocupó plaza en el Consejo de Estado. Murió en 1605.

120 Alonso de Portocarrero, marqués de Villanueva del Fresno y Barcarrota.

${ }_{121}$ Gaspar de Guzmán y Pimentel (1587-1645), III conde de Olivares desde 1607. Para conocer a fondo su trayectoria política remitimos a la gran biografía de ElLiotT, John H.: El CondeDuque de Olivares. Un políticio en una época de decadencia, Barcelona, Crítica, 1991.

${ }_{122}$ Cristóbal Gómez de Sandoval y Rojas, primogénito y destinado a suceder a su padre el duque de Lerma, era marqués de Cea y I duque de Uceda (desde 1609-1610) y gentilhombre de cámara del rey.

${ }^{123}$ Leonor de Sandoval y Rojas, hermana del duque de Lerma, aya de los infantes.

124 Lope de Moscoso Osorio.

${ }^{125}$ Infanta doña Ana, desde 1615 reina de Francia por su matrimonio con Luis XIII. 
no les pareze que la pueden tener de lo que aora se a hecho. Su nuera de V. A. me dizen que se hincó de rodillas delante de su Padre y le pidió esto del Conde de Altamira sin querer levantarse hasta que lo hiçiese, y diçen quel Rey se cansó de que le apretase tanto y le dixo con desabrimiento que acavasae ya y se levantase. No sé si es verdad. Hablando yo días a al Duque en que dezían que cubrían al de Altamira me dixo no le avía pasado por pensamiento y que era disparate. Bien sabrá V. A. que los de Altamira y sus hijos tienen de S. M. de 38 a 40.000 ducados cada año y lo que yo tengo es una encomienda que V. A., Dios la guarde, híçome me diese su padre y de su hermano de V. A. no tengo otra cosa sino mis gajes de que me deven mucho y la comida que me davan por los bosques me la quitaron. Y a mi hija [Antonia de Toledo] no le dieron ningún dote en tiempo que se davan muy grandes a todas las damas, pero nada desto no entivia el çelo, respecto y amor con que sirvo y serviré lo que durare.

Allá tiene V. A. quien save todo esto muy bien si quiere deçir lo que a pasado pero los privados y validos aunque no mientan encubren y no hablan claro. El de las Albriçias me a hecho y haze todos los malos offiçios que puede y en estando valido con el Duque como está aora. Yo estoy en muy ruin estado. También save harto desto si lo quiere deçir el que allá está [Rodrigo Calderón].

Suplico a V. A. me perdone el averla cansado tanto en esto que por dezirme V. A.. que andava averiguando en que topava este negoçio me a pareçido darle tan larga quenta dél para que sepa el rruin estado que tiene, pero yo callaré como V. A. manda hasta tener carta suya y tengo harta experiencia de la merçed que V. A., Dios la guarde, me ha hecho siempre y me hará.

An me dicho que la Condesa de Lemos y su hermano [Lerma] no están bien avenidos y que ella y su confesor hablan en yrse a Galiçia. Sospecho si es la causa el procurar gran merçed para sus hijos o cosas de don Rodrigo, que así lo piensan algunos. Con todo eso yo no acavo de creer que se aya de yr por que tiene muy buena vida y con mucha auctoridad y comodidad y no haze sino lo que quiere.

Ya escriví a V. A. quel casamiento del Duque de Uzeda ${ }^{126}$ avía çessado porque en [el Consejo de] la Cámara [de Castilla] no davan la facultad para cargar los 150.000 ducados y piénsase que por parte del de Uzeda no se solicita. Y así se entiende que no se hará. Aora para la venida del Duque de Umena cuelga el de Uzeda su cassa con unos damascos que me diçen que le prestan en las Descalças ${ }^{127}$. Afírmanme que quiere hazer almoneda. Están aora muy bien avenidos él y su padre [el Duque de Lerma]. Deve de ayudar a esto que el de Uzeda está gran amigo de la [Condesa] de Valencia ${ }^{128}$, la qual a tenido terçia-

126 «Ha venido aquí el duque de Cardona para hallarse a las escrituras y capitulaciones del casamiento de la hermana del marqués de Priego, su cuñada, con el duque de Uceda, a la cual dan en dote 20.000 ducados cada año", De Madrid, a 5 de mayo 1612, CABRERA DE CÓRDOBA, op. cit., p. 473.

127 Monasterio de las Descalzas Reales de Madrid.

${ }^{128}$ Luisa de Acuña y Portugal, condesa de Valencia de Don Juan. "Tiénese por muy cierto el casamiento del duque de Lerma con la señora condesa de Valencia, y que para efectuarlo solamente 
nas estos días y a sido muy visitada y rregalada del de Lerma y con ello acude allá toda la corte.

El Duque [de Lerma] no da audiençias y así aunque S. M. las da cada día padezen los negoçios y ay poco despacho según diçen. Yo no e estado en palaçio desde que S. M. llegó de San Lorenço porque vine un día antes con terçianas sençillas y víneme a curar a casa de mi hija donde estoy. Tuve quatro y con una sangría se me an quitado. Mi hija está con terçianas sençillas.

Con este último correo supimos cómo V. V. A.. A.. avían hecho su mayordomo mayor al Conde de Añover ${ }^{129}$ de que yo me e holgado mucho porque pienso que açertará a servir a V. V. A. A. y que el amor y çelo, y respecto con que yo le e oydo acá tratar desto me lo asigura. Guarde Dios a V. V. A.. A.. para que siempre nos hagan merçed a todos sus criados.

El de Umena entrará aquí mañana. Sale a rreçivirle a la puerta de Fuencarral el Duque de Alva ${ }^{130}$. Avíase tratado que le sacasen cavallos en que entrasen los hombres prinçipales que con él vienen, y él no a querido que entren sino en sus mulas de alquiler y que le saquen un cavallo para él y otro para quien él quisiere. A dado a entender que no se quiere yr hasta que llueva y acá desean que se vaya presto. [Endoso: Del Marqués mi señor para la ynfanta a 16 de jullio 1612\}.

VII. Carta de la Infanta Isabel al Marqués de Velada, Bruselas, 14 de septiembre de 1612, BL, Add. 28.698, fols. 185r.-186v.

Desconfianza de los correos ante el control que ejerce sobre la correspondencia Rodrigo Calderón. Pesimismo por el estado del »negocio« del marqués. La infanta lamenta la incomprensión que parece manifiestar su hermano hacia su petición.

se espera la dispensación del voto de religión de él y de castidad de ella; la cual es señora de muchas partes y hermosura, aunque ha engordado, com pasa de los cuarenta años; y si bien fue casada con el conde de Valencia, su sobrino, hijo mayor y sucesor del duque de Nájera, que murió antes que su padre, por estar muy enfermo cuando se casó se entiende que no pudo llegar a ella, y siempre ha sido muy estimada su descripción, y dicen que tiene de renta 14.000 ducados y grande recámara de cosas muy ricas y curiosas; y se dice que los duques de Uceda sienten mucho este casamiento, porque si hubiere hijos de él; tratará su padre [Lerma] de hacer mayorazgo de lo que había de acrecentar en la casa principal», De Madrid a últimos de julio de 1610, CABRERA DE CóRDOBA, op. cit., p. 412.

${ }^{129}$ Rodrigo Niño y Laso (+1620), II conde de Añover al suceder a su tío Juan Niño de Guevara. Era hermano del Conde de los Arcos Pedro Laso de la Vega. "Agora es mayordomo mayor el conde de Añover, cavallero español muy principal, y de muchos méritos. De pocos meses a esta parte los Archiduques le han honrado con este oficio, aviendo servido muchos años el de sumiller de corps, que retiene todavía, y juntamente en el de capitán de la guarda de lanças, y arcabuzeros», BENTIVOGLIO, op. cit., h. 55. Sobre el personal de la Casa de los archiduques véase LANOYE, Diederick: «Structure and Composition of the Household of the Archdukes» en THOMAS AND DUERLOO (eds.), op. cit., pp. 107-119 y GARCíA GARCía Bernardo: «La Corte de los Archiduques en Bruselas» en Torre de los Lujanes (Madrid) 44 (mayo 2001) pp. 59-75. lipe III.

${ }^{30}$ Antonio Álvarez de Toledo y Beaumont, $\mathrm{V}$ duque de Alba, gentilhombre de cámara de Fe- 
Marqués, no e osado fyar de correos esta carta por que todos pasan por manos de don Rodrygo y asý e aguardado a que la llebe el de Fyerstenberg ${ }^{131}$, que la dé en vuestras manos. Por ella beréys todo lo que ay de vuestro negoçyo. Don Rodrygo [Calderón] me a prometydo que a de açer en él marabillas y su amo [Lerma] está tan agradeçydo de lo que aquý emos echo con él que pienso que por pagármelo a de açer que my hermano os aga merçed. Aseguraos que será lo que más le encargaré y con más beras le pedyré. Está para partyr en bolbyendo el Marqués Espýnola ${ }^{132}$ de Alemanya y asý me pareçe que aguardéys a que llegue y os mostréys muy su amygo, dyçyéndole cómo yo os e escryto que lo es tanto vuestro y sy con este esfuerço que yo aré como dygo no os yçyere my hermano merçed, aunque yo tengo gran esperença que os la a de açer por este camyno. No me pareçe que ny bos ny yo tenemos mas que aguardar y asý os aconsejaría que no os cansásedes más en serbyr sino os fuésedes a vuestra casa pues pyenso que todo el mundo berýa la raçón que tenéys para ella y es arta lástyma mýa que no pueda ablar claro con mi hermano como serýa menester y que al cabo de treçe años que le suplyco una cosa no la yçyese pero como os dygo quedo con mucha esperança que desta bez sea de açer.

Todas vuestras cartas e reçybydo y olgado mucho con ellas y con todas las nuebas que me days aunque las quysyera mejores de vuestra salud. Procuradla, aunque no sea syno por vuestros hijos pues sabéys cuánto la an menester.

El de Fyerstenberg os dará nuebas de acá y asý no me alargo en ésta. Encomendadme mucho a vuestra hija y guarde os Dyos como deseo, de Brusselas, a 14 de setyembre 1612 . Isabel.

VIII. Carta de la Infanta Isabel al Marqués de Velada, Bruselas, 1 de marzo de 1613, BL, Add. 28.698, fols. 187r.-188v.

Agradecimiento por las nuevas recibidas de la corte. Preocupación por el estado de salud del archiduque Alberto.

Marqués, cuatro o cynco cartas e reçybido vuestras con que e olgado mucho pero no de que no ayan llegado a mys manos las dos que me avysáys de 26 y 29 de nobyembre en que me deçýades de los casamyentos del Almyrante y el

\footnotetext{
131 «Ha venido monseñor de Festemberg, de parte de los Archiduques de Flandes, a dar la norabuena de los casamientos de S.M.», De Madrid, 17 de noviembre 1612, CABRERA DE CÓRDOBA, op. cit., p. 502. Wratislaus I (1584-1631), graf von Fürstenberg, Werdenberg und Heiligenberg, desde 1599, gentilhombre de cámara del archiduque Alberto, caballero del Toisón. Para esta y otras identificaciones de caballeros del Toisón remitimos a La Insigne Orden del Toisón de Oro, edición de Alfonso de Cevallos-Escalera y Gila, marqués de la Floresta, Madrid, Patrimonio Nacional, 1996.

132 Ambrogio Spinola (1569-1630), duca di Sesto, marchese di Sesto y Benafro, principal hombre de confianza de los archiduques, honrado como caballero del Toisón de Oro tras tomar Ostende en 1604, maestre de campo general en Flandes y superintendente general de la Hacienda Real desde 1605.
} 
de Çea [n.l.]133 por donde se encamynan las cartas con todas las nuebas que me dáys en éstas e olgado mucho. Más quysyera me las dyérades mejores de vuestro negoçyo. El [conde] de la Olyba [Rodrigo Calderón] dyçe que açe y ará cuanto pudyere y o por no a acordallo plega a Dyos que aprobeche más que asta aquý que aora con el contento de ser capytán de la guardya podrá solyçytallo de mejor gana.

- A mucho pareçe que a comprado caro el de Barlamont ${ }^{134}$ el tusón para su yerno pues de buena raçón le abýa de tener de aquý a algunos años syendo su casa de las que lo an tenydo syempre. De aquý no se qué deçyros sy no que a my prymo [el Archiduque Alberto] le bolbyó la gota en la mano byen reçya para la que a tenydo alta aquý pero no como la de mi padre ${ }^{135}$ y byen será menester que no sea ansý porque aun que es byen sufrydo en dyçyéndole un poco reçyo luego se quyere açer remedyo y no basta tener un mundo de gotosos aquý, tullydos, de abérselos echo yo no ago syno predycalle, no sé sy a de aprobechar. An le sangrado dos beçes y pyenso que sy lo ubyeran echo el berano pasado no le acuydera tan a menudo. Tan byen se a purgado, que le a dexado byen flaco, que [trae] los pyes todavýa blandos.

Yo e pasado un muy gran catar[r]o casy dos meses. El tyempo a echo para todo de calyente y syn ynbyerno que es bueno para Flandes no aber podydo ençer[r]ar nyebe ny yelo. Pésame que a vuestra hyja le dure tanto su mal por que le deseo mucha salud y contento. Deçýdselo ansý, y guarde os Dyos como deseo. Abysadme sy my hermano gusta de un retablyllo que le embýo y sy llega byen tratado, de Brusselas, prymero de março 1613. Isabel.

IX. Carta de la Infanta Isabel al Marqués de Velada, Bruselas, 15 de abril de 1614, BL, Add. 28.698, fols. 190r.-192r.

Deterioro físico del archiduque Alberto aquejado de la gota. Interés por la situación de varios familiares del marqués. Lamenta la muerte de Cristóbal de Moura, amigo personal del marqués.

133 Juan Alfonso Enríquez de Cabrera, IX Almirante de Castilla y V duque de Medina de Rioseco, y Francisco de Sandoval, I duque de Cea, hijo del duque de Uceda. «Aunque traía intención S.M. de detenerse en El Pardo cuando vino de Castilla, llegó derecho aquí por ver al Príncipe, que todavía estaba con calentura [...] y luego se dio orden en hacer los casamientos del Almirante y del duque de Cea que se dilataron cuando fue el rey a Castilla para la vuelta; y a los 18 del pasado, se hizo en Palacio el del Almirante con la hija mayor [Francisca de Sandoval] del duque de Uceda, como estaba concertado desde que la Corte estuvo en Valladolid, y se esperaba que la dama cumpliese los doce años para casarse porque el Almirante tiene diez y seis [...]. El día siguiente se hizo el casamiento del duque de Cea con doña Feliche [Enríquez de Cabrera Colonna], hermana del Almirante, asemesmo en Palacio, la cual es de edad de diez y ocho años, y el duque de catorce», De Madrid, 15 de diciembre 1612, CABRERA DE CóRDOBA, op. cit., pp. 502-503.

134 Floris, comte de Berlaymont (+1626), gobernador del condado de Namur y más tarde de Luxemburgo. Caballero del Toisón de Oro desde 1584.

135 Felipe II (1527-1598).

Hispania, LXIV/2, núm. 217 (2004) 467-514 
Marqués, creo me abréys tenydo por byen dysculpada, con la ocupaçyón que e tenydo todo este ynbyerno con el mal de my prymo, de no aberos escryto y aora pudyera ser lo mysmo pues queda en la cama con la gota en la mano derecha y el codo y byen ynchado y asý no puede escrybyr, que en mudando un poco el tyempo para frýo o calor no ay ora sygura. Pyenso que sy los médycos no le ubyeran tenydo tanto ençerrado y quytado el exerçyçyo le ubyera ydo mejor. Aora que an caýdo en la cuenta byendo que le menudea más la gota con eso y. que se le mandan açer y que salga tyene ya los pyes tan flacos que pyenso no a de poder. Yo arto se lo e dycho pero no e podydo mas que sentyr ver que le echaban a perder. Graçyas a Dyos que la borrasca de allá de las byrne (?) las a pasado tan byen. Mucho e olgado con vuestras cartas aunque pyenso se an perdydo algunas y las que an benydo por bya de don Ýñygo de Cárdenas ${ }^{136}$ an llegado a mys manos a[ 1 ]cabo de un mes o dos por que no es onbre que escrybe acá aunque sabemos que le a mandado my hermano que lo aga algunas beçes. Lo a echo y asý se detyene las cartas mucho.

$\mathrm{E}$ olgado de que el casamyento de vuestro hyjo esté tan adelante y no me deçýs nada de vuestra hyja en estas cartas ny como le ba de salud. Byen creo os abrá pesado la muerte de [Johanna] Jaçyncourt ${ }^{137}$ aunque estaba byexa me açe arta falta. Allá a ydo su eredero, a buen syguro que de quexas de acá que syempre pyensa se le an quedado en casa con la myta[d] de la açyenda y pyenso que sy fuera por rygor que pydyeran pero doña Catalyna ${ }^{138}$ a andado tan puntual y cuerda en eso que no a tomado un alfyler syno lo que le tocaba.

Mucho me a pesado la muerte de don Chrystóbal ${ }^{139}$, no querýa ubyese dexado tan byen de hablar en su testamentarýa aunque no lo creo. Mucho cuydado nos dan estas cosas de Françya que se ban enconando tanto que yo no espero cosa buena byen olgara de pasar de aquý pero por yr con my prymo no puedo y asý acabo con que me encomendéys a vuestra hyja y os guarde Dyos como deseo, de Brusselas, a 15 de abryl 1614. Isabel.

X. Carta de la Ynfanta Ysabel al Marqués de Velada, Bruselas, 10 de diciembre de 1614, BL, Add. 28.698, fols. 193r.-194v.

Satisfacción por la concesión de la grandeza al marqués. Lamenta la pérdida de la relación de una comedia que le enviaba el marqués. Noticia sobre su salud.

\footnotetext{
136 Íñigo de Cárdenas Zapata, embajador español en Francia.

137 Johanna Jacincourt, camarera mayor de la infanta Isabel.

138 Catalina de Livia, sobrina de Johanna Jacincourt, hacía las veces de camarera mayor por la avanzada edad de su tía, BENTIVOGLIO, op. cit., h. 55.

139 Cristóbal de Moura, I marqués de Castelo Rodrigo, consejero de Estado y antiguo virrey de Portugal.

Hispania, LXIV/2, núm. 217 (2004) 467-514
} 
Marqués, byen creeréys que como quyen a sydo la que más a deseado la merçed que my hermano os a hecho asý e sydo la que más a olgado de saber que esto se aya concluydo, graçyas a Dyos que çyerto yo estoy muy contenta y deseando la goçéys muchos años. Tan byen lo estoy de que aya salydo vuestra nuera [Constanza Osorio] tan a vuestra satysfaçyón. De vuestra hyja deseo saber como le ba y a donde está que con estos postreros correos que an benydo no e tenydo cartas vuestras. Temo se ayan perdydo por que me a dycho el [Conde] de Añober que le escrybe su hermano [el Conde de los Arcos] ${ }^{140}$ que me enbyábades la relaçyón de la comedya y no a llegado a mys manos. Debe de aber sydo muy buena y yo olgara arto de ver al Prýnçype y a sus hermanos. Graçyas a Dyos que todos estan buenos y my hermano.

My prymo lo está en estos dýas que no es poco para el tyempo que açe de agua y una calor que los más dýas no se pueden ençender lumbre. Yo no e andado buena estos dýas de un dolor en un lado que me suele dar algunas beçes en no açyendo exerçyçyo y dyçen los médycos es ramo de cólica. Los otros dýas me dyo byen reçyo y asý me purgaron pero no me a aprobechado mucho que ayer me tornó a dar que no e de estar en la cama. Tras esto a myl dýas que traygo muy gran catar[r]o que me ará no alargarme en esta aunque ubyera byen en que quando las cosas de aquý no están como yo quysyera aunque creo no se lo pareçe asý a todas. Plega a Dyos que las de Ytalya bayan mejor. Estamos llenos de güespedes como escrybyrán otros y ya acabo con que os guarde Dyos como deseo, de Brusselas, a 10 de dyçyembre 1614. Isabel.

XI. Carta de la Infanta Isabel al Marqués de Velada, Bruselas, 30 de marzo de 1615, BL, Add. 28.698, fols. 196r.-197v.

Nuevas familiares. Llegada del archiduque Leopoldo a Flandes. Sobre la situación en el principado de Jülich-Cleves. Contento por la sorpresa que causó en la corte de Madrid la llegada de Alberto Struzzi con el enano Miguel Soplillo y un ejército de juguete para Felipe III y sus hijos.

Marqués, la postrer carta que tengo vuestra es de dos deste mes. E olgado tanto con ella como lo ago syempre con todas aunque echo [de] menos que no me déys nuebas en ella de vuestra jente que estaba con cuydado de que me escrybystes [que] quedaba vuestra hyja con calentura. De todas las nuebas que me dáys e olgado mucho y de que my hermano esté ya bueno de su catar[r]o que me a tenydo con mucha pena lo que le a durado. Yo le tengo aora tan grande de tres dýas acá que a entrado el calor muy de golpe que no podré escrybyr largo.

140 Pedro Laso de la Vega, I conde de los Arcos (desde 1599), nombrado mayordomo de la Casa del príncipe don Felipe (IV). 
My prymo anda bueno estos dýas graçyas a Dyos aunque los pyes syempre se están blandos pero a podydo andar dos beçes en tryneo las Carnastollendas. Paréçeme que en todas partes nos ba byen de güespedes que [el] dýa de Nuestra Señora se nos apareçyó súpytamente el Archyduque Leopoldo ${ }^{141}$ mas no estubo syno un dýa. Es su hermana propya en el umor. Lo de Julyers [Jülich] 142 se anda conpunyendo sy los de Françya no lo desbaratan que a my pareçer en todo lo que ponen la mano ayudan de muy buena gana a los de Olanda con esta materya de estado que tyenen en la cabeça de contrapesar a España, plega a Dyos se remedye esto con los casamyentos. En más basaban en Françya el braçalete que syempre se nos le an bendydo por doçyentos myl ducados. Güélgome apruebe byen el enano [Miguel Soplillo] y aya contentado el exérçito. Alberto Estruçy ${ }^{143}$ me pyde os le encomyende y asý lo ago y me pareçe le conoçeys muy byen el umor.

A vuestra hyja y nuera ${ }^{144}$ me encomyendo mucho y guarde os Dyos como deseo, de Brusselas, a 30 de março .1615. Isabel.

XII. Carta de la Infanta Isabel al Marqués de Velada, Mariemont, 23 de mayo de 1615, BL, Add. 28.698, fols. 199r.-200v.

Deseos de poder ver a sus sobrinos. Preocupación por la situación de la joven reina de Francia, Ana de Austria. Noticia del envío al marqués de un papagayo. Persiste la gota del archiduque Alberto.

Marqués, dos cartas vuestras e reçybydo estos dýas y olgado mucho con ellas por que son las más frescas nuebas que e tenydo de aý. La que byno por Françya aunque don Ýñigo [de Cárdenas] las detubo tantos dýas como suele

${ }_{141}$ Archiduque Leopoldo de Estiria (1586-1632), obispo de Passau y Estrasburgo, hermano de la reina Margarita.

142 "Muerto sin hijos Guillermo Duque de Cleves a los postreros de março de 1609, y faltando la línea de varón de aquella Casa, muchos Príncipes de Alemania se movieron luego a pretender la herencia de sus Estados, respecto del derecho que quedava en las líneas de hembra», BentivoGLIO, op. cit., h. 141.

${ }_{143}$ Alberto Struzzi, antiguo servidor de Alejandro Farnesio, duque de Parma, fue desde 1603 hasta 1614 representante del duque Ranuccio I ante los archiduques. Nombrado gentilhombre del archiduque Alberto fue enviado en 1614 a España con el encargo de averiguar las intenciones de Felipe III sobre la sucesión de Flandes. En noviembre llegó a Madrid llevando dos presentes de los archiduques, un ejército de juguete para el infante don Fernando y el enano Miguel Soplillo para el rey. Para conocer en profundidad su biografía véase ECHEVARRía BACIGALUPE, Miguel Ángel: $A l$ berto Struzzi. Un precursor barroco del capitalismo liberal, Lovaina, Leuven University Press, 1995.

${ }_{144}$ Constanza Osorio, hija del VIII marqués de Astorga Pedro Álvarez Osorio, era hermana y heredera de Álvaro Pérez Osorio, IX marqués de Astorga. Casó en 1614 con el único hijo varón y heredero del marqués de Velada, Antonio Sancho Dávila Toledo Colonna, I marqués de San Román y futuro III marqués de Velada (1590-1666).

Hispania, LXIV/2, núm. 217 (2004) 467-514 
mucho e gustado de todas las nuebas que me escrybýs y de cómo dançó el Prýnçype y sus hermanos que me a puesto grandýsyma enbydya de no podellos ber. Lo demás, de cómo se crýan y su condyçyón e sabydo tan byen por otras partes y lo syento arto y byen a menester la Reyna de Françya ${ }^{145}$ todo lo que sabe para lo que le aguarda que no está aquello para menos. Urquina ${ }^{146}$ que lleba ésta os dará nuebas de todo lo de acá muy particulares que asý se lo e dycho y de nuestra romerýa a donde nos os olbydé y a vuestros hyjos, tan byen dyrá de my reynado, de que enbýo una gran relaçyón a my hermano. Con el papagayo os abréys olgado y espero vuestra norabuena por que yo las reçybo de muy buena gana que me pareçe con mucha raçón pues reynado que e ganado por my mano y que no trae otro mayor cuydado, que bestyr los gygantes se puede estymar en mucho. Todo nos lo agua esta gota de muy prymo que syempre byene cuando más embaraça y asý no nos a dexado salyr al campo ny pyenso nos dexará yr a Brusselas a la pruçysyón como pensábamos para que my fyesta fuera cumplyda. El tyempo a echo tal de fryo y nyebe y granyço y otros dýas de grandýssyma calor que no aguardaba yo menos porque quysyera la ubyera pasado en Brusselas a donde le començó por que no dygan luego que lo açe el pobre Marymont como suelen los que se cansan dél porque aora llegó con un pye de manera que luego se ubo de acostar y oy açe ocho dýas que ya en pye ya en la cama se pasa. No sé sy mañana se podrá lebantar y por yr a estar con él no me alargo más. Paréçeme se muryó su sobryno de [Johanna] Jaçyncurt. Todos le abýan profetiçado que goçarýa poco la erençya por aber sydo llebada syn raçón. Su sobryna se casó el lunes de casymodo, espero estará muy byen y ella a proçedydo muy cuerdamente en su casamyento aun que a tenydo artos contraste.

A vuestra hyja y nuera me encomendad mucho y guarde os Dyos como deseo, de Marymont, a 23 de mayo 1615. Isabel.

XIII. Carta de la Infanta Isabel al Marqués de Velada, Bruselas, 24 de noviembre de 1615, IVDJ, Envío 38, Caja 50, doc. 86.

La infanta expresa su deseo de escribir al marqués en respuesta a las cartas recibidas. Le han prevenido de la inseguridad de los correos ante las agitaciones que los protestantes - liderados por el príncipe de Condé- promueven en Francia contra la regente María de Médicis. El archiduque Alberto ha acudido a recibir a su hermano Maximiliano a Lovaina. Le traslada al marqués su desconcierto ante la escasez de noticias sobre los Casamientos y las nuevas que al respecto le han llegado. Doña Isabel, metida a casamentera, recuerda los deseos del exiliado duque de Aumale de casar a su hija y heredera con un grande español.

\footnotetext{
145 Ana de Austria, casada en 1615 con Luis XIII de Francia (+1643).

146 Mateo Urquina, secretario de los archiduques Isabel y Alberto.
} 
Marqués, aún creo que abrá correo presto. Me dyçen yrán más syguras las cartas con el ordynaryo por estas rebueltas de Françya y asy lo e querydo escrybyros con éste y tan byen por goçar de tener oy más tyenpo con aberse ydo my prymo esta mañana a Lobayna ${ }^{147}$ a reçybyr a su hermano el Archyduque Maxymylyano ${ }^{148}$, que llegará mañana aquý. Andamos muy ocupados con el ospedaxe y en procurar tenelle algunas fyestas aunque es ombre de muy pocas çerymonyas.

A cuatro cartas vuestras debo respuesta. Con todas e olgado mucho y más con estas postreras que son las más frescas nuebas que tenemos de aý, por que por Françya dyçen an tomado no se cuántos cor[r]eos los erejes y el de Condé149, que todos están en el camyno y asý no sabemos palabra ny sy an sydo las Entregas ${ }^{150}$ o sy a llegado la Reyna [María] ${ }^{151}$ a Burdeos, que me tyene con mucho cuydado y más lo que a dycho un nabýo que a benydo a Olanda. Que my hermano abýa ydo encubyerto a Bayona, que con lo que bos me escrybýs temo debe de ser verdad. Aquý nos abýan echo muerta a la Condesa de Puño en Rostro ${ }^{152}$. Dýas abýa que lo abýan escryto de Françya y asý me e olgado mucho de ver por vuestra carta que está mejor aunque syento mucho no baya con la Reyna aora y que no enbýen otra persona syno las que me deçýs. No se dónde las an ydo a buscar y no es lo que la Reyna abýa menester aora a los prynçypyos. Dyos la alumbre que byen lo a menester para en lo que se byene a meter. Yo e tomado aora por Camarera Mayor una hermana del Duque de Aryscot ${ }^{153}$ que es una muy buena mujer y que ará lo que le mandaren syn ruydo. Sólo no se puede sentar en baxo. Artas faltas le an puesto algunos que no deseaban que yo tomase Camarera Mayor pero yo no estaba byen syn ella y asý la e tomado de lo mejor que aý por acá. A estado en Alemaña en casa de my týa [la emperatriz María] ${ }^{154}$ y sydo dama de la Reyna de Françya [Isabel de Austria], hermana de my prymo ${ }^{155}$.

147 Leuven (Lovaina), Bélgica.

148 Archiduque Maximiliano de Austria (1558-1618).

149 Henri de Bourbon, prince de Condé (1588-1646).

150 Casamientos o Entregas así se denominaron los Dobles Matrimonios con Francia. El intercambio de princesas tuvo lugar en Bidasoa en 1615: Véase MANTUANO, Pedro: Casamientos de España y Francia, Madrid, Imprenta Real, Tomas Junta, 1618, RB, VI/2854.

151 María de Médicis, viuda de Enrique IV (+1610).

152 Hipólita de Leiva, viuda del IV conde de Puñonrostro, Francisco Arias Dávila y Bobadilla.

153 Anne de Crö̈ (1564-1635), V titular de la Casa de Aerschot al suceder a su hermano, el difunto Charles II de Crö̈, IV duc de Aerschot $(+1612)$ y caballero del Toisón, y esposa del príncipe d'Aremberg, Charles de Ligne (+1616), caballero del Toisón (desde 1584), véase Une ville et ses seigneurs. Enghien et Arenberg 1607-1635, Bruselas, Crédit Communal. 1994.

154 María de Austria, hermana de Felipe II, esposa del emperador Maximiliano II. Murió en Madrid en 1603.

155 Isabel de Austria (1554-1592); hija del emperador Maximiliano II y María de Austria, fue reina de Francia por su matrimonio con Carlos IX. Tras enviudar se retiró al convento de carmelitas descalzas de Viena.

Hispania, LXIV/2, núm. 217 (2004) 467-514 
Mucho me pesa de la poca salud que tyene vuestra hyja y de que aya estado malo vuestro nyeto ${ }^{156}$. Yo le quysyera aora de más edad para casalle que me an echo casamentera aora y no se a quyen encomendarme mejor que a bos para que me dygáys qué grandes ay en España por casar que debajo de secreto os dyré que el Duque de Umala [Aumale] ${ }^{157}$ me a pedydo le case su hyja ${ }^{158}$ en España y ella tan byen lo desea por que los con quyen podýa casar en Françya son estos prýnçypes mal contentos y asý dyçe no quyere casar con traydores. Ella es su eredera, que no tyene otra, ny hijo y a eredado a su madre, y padre e hija están resueltos de bender toda su açyenda que cuando muy poco se saque della serán más de ochoçyentos myl ducados por que es muy buena su sangre. Lo es por que es la de Lorena. Ella tyene beynte años aun que pareçe de más. Es gorda y fresca y grande y toda junta pareçe arto byen y tyene muy buena condyçyón como os dygo. Sy vuestro nyeto tubyera más edad me pareçe le estubyera arto byen pero ya que esto no puede ser, aconséjame en quyen os pareçe que pongamos los ojos y cómo lo guyaremos.

De aquý no sé otra cosa que deçyr syno que aguardo con alboroço a Juan de las Ynfantas con las chobas y por que me boy a ver ensayar a las damas de una fyesta que quyeren açer, acabo con que os guarde Dyos como deseo, de Brusselas, a 24 de nobyenbre 1615. Isabel.

XIV. Carta de la Infanta Isabel al Marqués de Velada, Bruselas, 13 de enero de 1616, BL, Add. 28.698, fols. 202r.-204v.

Satisfacción por la celebración de los Casamientos. Interés por cómo se acomoda a la corte la princesa Isabel. Preocupación por su sobrina la reina de Francia.

Marqués, çynco cartas vuestras e tenydo estos dýas con que e olgado muchýsymo y no sé cómo agradeçeros el cuydado que tenéys de abysarme de todo que es sacarme a mý dél y más aora del que tenýa como se arýa la Jornada de las Entregas, graçyas a Dyos que conçedyó todo tan byen arto. Deseo ya cartas para saber cómo le ba a la Prynçesa [Isabel de Borbón] y [si] se acomoda en todo, plega a Dyos sea como yo deseo y muy a gusto de my hermano y de su marydo [el príncipe Felipe], que sygún el umor que me dyçen tyene temo no an de ser muy byen casados. De la Reyna de Françya [Ana de Austria] sabemos que lo está mucho pero no abrá partycularydad por que toman todas las

156 Antonio Luis de la Cerda y Dávila, VIII duque de Medinaceli, nacido en 1607.

157 Charles de Lorraine, duc d'Aumale, jefe de la Casa de Lorena, exiliado en Flandes tras condenarle el Parlamento de París de traidor por sus tratos secretos con España. Sirvió a los archiduques como gobernador de Binche y Mariemont.

158 Anne de Lorraine (1600-1638), hija y heredera del duc d'Aumale, casó finalmente en 1618 con Enrico di Savoia, duc de Nemours (1572-1632).

Hispania, LXIV/2, núm. 217 (2004) 467-514 
cartas. Yo la e escryto y enbyado la carta al [duque] de Monteleón ${ }^{159}$ para que se la dé por que no e querydo aguardar a que le enbyemos la norabuena que sygún las cosas de aquel reyno no sé cuando podrá ser.

Gran lástyma le açe que tan presto aya allado la Reyna tantas pesadumbres y que no tenga cabe sý syno las que me escrybýs que le an dado y aún esas dyçen aquý se an buelto ya a España como yo syempre ymagyné. Yo deseo mucho podella serbyr dende aquý y asý lo procuraré cuanto pudyere.

Nuestro güesped [Archiduque Maximiliano] se fue ya. Pareçe ba contento y asý lo emos procurado y yo que me tenga por mejor cuñada que la Emperatriz ${ }^{160}$. A mi hermano enbýo una relaçyón muy larga de todas las fyestas y lo que se a echo dende que byno asta que se fue. Pyenso os la mostrará y para que gustéys más della os enbýo ese papel que emos reýdo aquý con él. No me deçýs por autor y sy le quysyéredes mostrar a my hermano açedle sacar de otra letra. Aquý estamos buenos y aunque le tocó la gota a my prymo la paseva fue poco y sanó con camynar para despedyrse de su hermano [Maximiliano], el cual tan byen tubo doçe dýas la gota. Aquý se açe myl remedyos para ella que no sé cómo no le matan y todos de su cabeça syn ber ny oýr dotor.

De toda vuestra jente e olgado mucho de saber. Deseo los abréys allado muy buenos a los que quedaron en Madryd. Abysádmelo syempre y guarde os Dyos como deseo, de Brusselas, a 13 de enero 1616. Isabel.

XV. Carta de la Infanta Isabel al Marqués de Velada, Bruselas, 6 de marzo de 1616, BL, Add. 28.698, fols. 205r.-208v.

Felicitación por el nacimiento del nieto del marqués. Contento por la remisión del Quijote con cuya lectura pareció disfrutar durante los Carnavales. Preocupación por la delicada situación de la flamante reina de Francia y por la crisis políti-

- ca del reino, con agitaciones y revueltas propiciadas por el príncipe de Condé y otros nobles protestantes contrarios a la orientación procatólica de la regencia de María de Médicis y favorables a su exclusión del gobierno. Continúan las negociaciones matrimoniales del duque de Aumale para casar a su hija y heredera.

Marqués, aunque deseé el otro dýa escrybyros no pude y me pesó por aber de aguardar asta aora a daros la norabuena del nyeto que os a naçydo ${ }^{161}$ de que yo e olgado tanto que no os lo sabrýa encareçer y asý os doy la norabuena de bonýsima gana aunque sea açernos tan byejos que los que dexamos cryaturas

\footnotetext{
159 Héctor Pignatelli Colonna, duque de Monteleón. Sustituyó a Íñigo de Cárdenas en la embajada española en París tras los Casamientos.

${ }_{160}$ Ana (1585-1618), hermana del archiduque Fernando II del Tirol, casada con el emperador Matías en 1610.

161 Antonio Pedro Dávila Osorio Toledo, IV marqués de Velada y II de San Román, y desde 1659 X de Astorga al suceder a su tío Álvaro Pérez Osorio muerto sin sucesión.
} 
tengan ya hijos. Muy byen lo a echo vuestra nuera [Constanza Osorio]. Dadle la norabuena de my parte que por vuestra nuera la quyero mucho. Deseo saber qué tan contento está vuestro hijo [Antonio Sancho, marqués de San Román] con el suyo. Pésame que el de la Duquesa [de Medinaceli] y ella ayan estado tan malos como me deçýs y asý deseo ya tener nuebas de que ayan llegado aý con salud y e echado de menos no aber tenydo carta vuestra ny con el ordinario ny con un correo que byno el otro dýa con el duplycado de las letras que sygún está lo de Françya no fue poco llegar acá.

Con todas las nuevas que me abéys escrito e olgado mucho y con el papel de los aposentos. Aquý os enbýo otro de las dudas que deseo saber sobre ellos. Tan byen os agradezco a don Quyjote ${ }^{162}$ que a sydo todo my pasatyempo estas carnastollendas y sy ubyera llegado más tenprano quyçá ubyeramos sacado algo dél para alegrallas pero no faltará alguna ocasyón.

La que tubystes para vuestra gota fue byen grande y me pesa os aya durado tanto. My prymo está mejor de la suya que aunque le a tocado dos o tres beçes a sydo muy moderadamente y para el tyenpo que a echo es arta mejorýa por que a sydo el mayor frýo que e bysto y a estado cuatro semanas la tyer[r]a con una bara de nyebe y aora que abýa echo buen tyenpo a buelto oy a nebar.

Nuestro güesped [Archiduque Maximiliano] fue muy contento, que aora que está en Praga escryben todos de allá que no ablan él y sus cryados en otra cosa syno en cómo los emos regalado con que se puede consolar el Conde de Añober que arto lo a trabaxado. Y yo estoy byen sygura cuán de buena gana nos ayudaredes y no es menester estas ocasyones para echaros menos, en fyn, le a balydo el ospedaxe para que la Emperatryz [Ana] le aya echo açer un baylete a sus damas a conpetençya del nuestro, el cual le contentó tanto que dyçen por todo donde an ydo no saben hablar en otra cosa. Yo, en açyendo alguna fyesta destas luego, estoy llorando por que no la puede ver my hermano. Muy contento pareçe que está con su nuera [la princesa Isabel de Borbón] graçyas a Dyos. Pero sygún oygo por acá del Prýnçype temo no será tan byen casado como su padre. Deçydme quyén es doña Juana Çapata ${ }^{163}$, la que me deçýs que está en su aposento.

La Reyna de Françya está buena pero lo que a pasado por el camyno y de la manera que está serbyda me tyene lástymadísima y no podello remedyar y para que todo baya byen. Las que a llebado de aý están como perros y gatos unas con otras. Gran yer[r]o a sydo enbyalla con aquella gente y syn una persona de pecho que pudyera hablar a su suegra [la Reina María de Médicis] aunque ella se syrbe de la mysma manera que los moços de coçyna le traen la byanda y

${ }^{162}$ Se trata de la segunda parte de Don Quijote publicada en Madrid en 1615 por el impresor Juan de la Cuesta. La infanta suponemos conocería la primera parte aparecida en 1605 en Madrid o quizás la edición de Bruselas de 1607, la primera castellana que se editaba fuera de la Península Ibérica. La primera edición completa de la obra de Cervantes vio la luz en Barcelona en 1617.

${ }_{163}$ Juana Zapata, hija de Francisco Zapata de Cisneros, I conde de Barajas, esposa de Mosén Rubí de Bracamonte, señor de Cespedosa y Fuente del Sol. 
cosas a este tono que yo pyenso que no se saben allá y el [Duque] de Monte León açe lo que puede y no puede nada por que no se les da nada por él y asý está desesperado y pyenso tratará presto de bolverse. Ubyérase de aber capytulado cómo se abýa de serbyr la Reyna y que don Ýñygo [de Cárdenas], pues dyçen gobernaba a la Reyna madre, no se ubyera benydo asta que estubyera la casa puesta y todo asentado. La Reyna muy byen lo syente pero lo dysymula con arta cordura que es arto en sus años. Las cosas de aquel reyno ban muy mal y todo está destruydo y este conçyerto que se açe aora no es syno para açer mejor su hecho, los uguenotes, como dyrá el tyenpo, sy Dyos no pone la mano en ello. Yo e escryto dos beçes a la Reyna, la prymera se a perdydo, no se sy abrá llegado la segunda. Dyçen se le muryó su médyco que le abýa pesado arto para que le dexasen quedar. Tan byen es muerto el médyco judýo, gran pryvado de la de Ancré ${ }^{164}$, y no a sydo muy llorado de todos.

Los buenos del casamyento de la Umala no se qué os dyga por que el mysmo correo que trujo vuestra carta trujo una del de Lerma para el [Marqués] de Guadaleste ${ }^{165}$ en respuesta de una que él le escribyó de parte del Duque de Umala ofreçyéndole su hija para el Duque de Uçeda u syno para cosa suya y el de Lerma responde agradeçyéndoselo mucho pero que su hyjo no se quyere casar y que cuando se ubyera de casar está prendado en otra parte y que, asý pues, desea casa suya. La casará con el [Marqués] de Lombay ${ }^{166}$. Esta carta mostró el de Guadaleste a my prymo y nos emos quedado espantados. El de Umala dyçe que nunca tal dyxo al de Guadaleste syno que en conbersaçyón dyxo que quyen le casase a su hyja en España se lo pagarýa y él a escryto al de Lerma, dyçen syn prendarse, porque tan byen me an dycho en secreto que a respondydo el de Guadaleste que el Duque y su hyja están muy contentos. La hyja no lo está porque le an dycho que es muy chyco de cuerpo el nobyo y con muy poca açyenda. Nosotros callamos asta ver en que para esta maraña que no será la prymera que abrá echo el de Guadaleste, que es tan amygo de açer byen a todos que algunas beçes se pyerde. El de Umala es bonýsimo pero no es para negoçyos y asý arán dél lo que quyeren. Tan byen me pareçe que la hija no está en bender la açyenda de Françya ny en perder su casa por que el padre lo quyere bender todo. Sy entendyéredes algo por allá syn daros por entendydo me lo abysad. De aquý no ay cosa que deçyr syno que partyrá un dýa destos el de Bucoy ${ }^{167}$ que embyamos a

${ }^{164}$ Eleonora Galigai, esposa de Concino Concini, maréchal d'Ancré, privado de la reina María de Médicis.

165 Francisco de Mendoza, almirante de Aragón, casado con María Ruiz Colón de Cardona, duquesa de Veragua y marquesa de Guadaleste, representante de Felipe III ante los archiduques $\mathrm{Al}$ berto e Isabel. Fue también caballerizo mayor de Alberto.

166 Francisco Diego de Borja y Aragón (1596-1664), IV marqués de Lombay y futuro VIII duque de Gandía, hijo de Francisco Carlos de Borja Aragón y Centelles (1573-1623), VII duque de Gandía.

167 Charles-Bonaventure de Longueval (1571-1621), II comte de Bucquoy, maestre de Campo General desde 1614. Fue gentilhombre de cámara del archiduque Alberto, consejero de Estado y Guerra, capitán general de la Artillería y caballero del Toisón (desde 1612).

Hispania, LXIV/2, núm. 217 (2004) 467-514 
dar la norabuena a my hermano y al prýnçype y guarde os Dyos como deseo, de Brusselas, a 6 de março 1616. Isabel.

XVI. Carta de la Infanta Isabel al Marqués de Velada, Bruselas, 20 de abril de 1616, BL, Add. 28.698, fols. 212r.-214r.

Acuse de recibo de unos papeles del palacio de Aranjuez y de la relación de la jornada de los Casamientos, ésta bien diferente de la enviada por Felipe III, en extremo laudatoria del papel desempeñado en ella por el duque de Uceda. Alabanzas hacia el conde de Berg y el marqués de Villafranca por sus méritos militares.

Marqués, tres cartas vuestras e reçybydo juntas y olgado mucho con estas y con las nuebas que me dáys de la buena salud de my hermano y sus hijos, bendyto sea Dyos. Tan byen e olgado mucho de que bos y los vuestros la tengan y olgara arto de ber vuestros nyetos. Pésame que la Duquesa, vuestra hyja, no acabe de estar buena y a me espantado la poca merçed que me deçýs le an echo, pues en verdad que quando no fuera vuestra hyja la mereçýa ella por sý.

La relaçyón de la Jornada e olgado de ber. Es dyferente de la que enbyó my hermano, que no pareçe se yço para otra cosa que loar al de Uçeda y su dyscreçyón y como pyenso que os e escryto me an espantado mucho algunas cosas della. Lo uno que cuando la Reyna de Françya [Ana de Austria] partyó para yr a las Entregas dyçe que él yba en una lytera delante de la de [la] Reyna y lo mysmo cuando bolbyó con la Prynçesa [Isabel de Borbón], y lo otro, que al otro dýa cuando fue al aposento de la Prynçesa se sentó delante della en una sylla rasa que todos los otros grandes se quedaron allý en pye.

Muy byen byno el papel de los aposentos y aunque yo ymajynaba que se entraba al cuarto nuebo por donde me deçýs me pareçýa que la pyeça donde yo dormýa y la guardaropa quedarýan muy oscuras y aora me lo pareçe [y] más abyendo quytado la bentana que caýa al Jardýn [roto] Felype.

Las relaçyones que yo enbýo a my hermano las açe un ayuda de my guarda que es todos mys pyes y manos por que tyene la mayor abylydad para cuantas cosas ay que yo [le] confýo. Y pynta y dybuja muy byen y es como una dueña que no es ya moço y asý syempre le traemos ocupado my prymo y yo.

Bonýsyma fue la caça de los lobos y no sabýa que vuestro hyjo era tan buen caçador que e olgado mucho dello. Byen creo que aý no dyçen todo lo que pasa en Françya. Aquý sabemos más de lo que yo quer[r]ýa saber no pudyendo remedyallo. Todas las beçes que puede me escrybe la Reyna y dýçeme que asta aora no puede deçyr, que sé [n.l.] byen y a la berdad no le faltan arta raçón para estar descontenta. Yo la procuro alentar todo lo que puedo [n.l.] arto bella desta manera, Dyos le ayude y alumbre estos dýas asý de mylagro no [n.l.] el rey quyryendo guyar un coche como cochero. Grandes partes escrybe el de 
Lerma del Cardenal Panyagua ${ }^{168}$. Aquý se ha dycho le embýan a Alemanya que con la otra enbaxada que, me escrybýs, se procuraba serýa para dar con todo al trabés. Tan byén han dycho aquý que abýan estado las damas cuatro dýas syn tener qué comer y que tenýan presos los guardas por que dexaron entrar comyda de otras partes para las françesas, serýa bueno. Aquý lo estamos y asý partymos mañana para nuestra nobena de cada año a Nuestra Señora de Monteagudo ${ }^{169}$. Açe muy lyndo tyenpo y asý lo está el campo. Allá sabréys los lugares que se an tomado en Julyers [Jülich]. A lo echo my byen el Conde Henryque $^{170}$ y a my juyçyo de su profysyón es el onbre de más serbyçyo que ay aora. Paréçeme que don Pedro de Toledo ${ }^{171}$ a echo lebantar el çerco de Gradys$\mathrm{Ca}^{172}$, plegue a Dyos que ponga en raçón al de Saboya ${ }^{173}$. A vuestra hyja y nuera me encomyendo mucho y guarde os Dyos como deseo, de Brusselas, a 20 de abryl 1616. Isabel.

XVII. Carta de la Infanta Isabel al Marqués de Velada, Bruselas, 10 de mayo de 1616, BL, Add. 28.698, fols. 214r.-216v.

Preocupación por la caída sufrida por el marqués y sus consecuencias. Relación breve de una romería y de la boda de unos servidores. Mención a la situación política europea tras la paz de Asti (1615). Desconsuelo por los padecimientos de su sobrina la reina de Francia. De nuevo comentarios a propósito de las trazas de Aranjuez.

Marqués, ayer y antyyer e reçybydo tres cartas vuestras con el ordynaryo y correo que llegó tras él y con ellas e olgado tanto como syempre y de saber la buena salud de my hermano y sus hijos y que la calentura del Ynfante don Fernando no pasase adelante. A me pesado de vuestra caýda y que os oblygase a sangrar y echo mucho [de] menos que no me deçýs nada de vuestros hyjos y nyetos, que syempre les deseo mucha salud. Aquý la tenemos y emos buelto de

\footnotetext{
168 Cardenal Gabriel Trejo Paniagua.

169 Santuario de Nuestra Señora de Monteagudo (Scherpenheuvel), muy vinculado a la política contrarreformista de los archiduques tras las victorias de Bois-le-Duc y Ostende.

170 Henri, comte de Berghes, comandante de la caballería alemana, al servicio del archiduque Alberto, véase Correspóndanse de la cour d'Espagne sur les affaires des Pays-Bas au XVIIe siècle, edición a cargo de Henri Lonchay y Joseph Cuvelier, Bruselas, Kiessling, 1923, vol. I, p. 429.

171 Pedro de Toledo Osorio, V marqués de Villafranca del Bierzo, consejero de Estado y gobernador general de Milán, primo y cuñado del marqués de Velada.

172 Gradisca, ciudad de la costa este del Adriático perteneciente al archiduque Fernando de Estiria, fue sitiada por Venecia en 1615 gracias al apoyo inglés y holandés, dando lugar a la llamada "guerra uscoque" que se prolongó hasta 1617, véase PARKER, op. cit., pp. 35-37. Para la citada guerra véase también BRACEWELL, Catherine Wendy: The Uskoks of Senj. Piracy, banditry and Holy War in the sixteenth-century Adriatic, Ithaca-Londres, Cornell University Press, 1992.

173 Carlo Emanuele, I duca di Savoia -cuñado de la infanta Isabel-, se destacó por su apoyo a la República de Venecia en contra del archiduque Fernando de Estiria (futuro emperador Fernando II).
} 
nuestra romerýa con byen que aunque a my prymo le tocó un poco la gota en las manos no nos estorbó syno un dýa de la nobena, que çyerto pareçe que Nuestra Señora nos açe en yendo allý merçed, que a buelto my prymo mejor que a muchos dýas le bysto. Emos estado dyex y syete dýas fuera con muy buen tyenpo aun que tan byen abýa falta de agua pero los postreros dýas llobyó muy byen y es lyndýsyma toda aquella tyer[r]a. El dýa que partymos y el que llegamos a Nuestra Señora nos yço tal calor que se muryeron tres caballos y el uno de nuestro coche y aora açe fryo.

Emos tenydo ayer y oy una muy buena boda de un menyno y una menyna que el dýa antes tomaron espada y chapines y a ella le dyeron terçyanas en el camyno pero por ser chycas no se dyfyryó la boda y al tyempo de la belaçyón le dyo el frýo que nos emos bysto en gran trabaxo por que cada credo se desmayaba la nobya. Yo creo [que] otros escrybyrán toda la ystorya más partycularmente que toda a sydo boda de reýr por sus pocos años. Yo lo e echo con los dos papeles que me abéys enbyado y e estrañado el [n.l.] que se lebantaba la Prynçesa cuando suben al estrado que en my tyenpo no se lebantaban syno cuando llegaban a pedyr la mano y syno me acuerdo mal me pareçe que oý syempre que la Duquesa de Güescar ${ }^{174}$ fue la prymer[a] nuera de grande a quyen se dyo almoada cuando se casó my madre ${ }^{175}$ en Toledo.

Las cartas del de Osuna ${ }^{176}$ son estremadas y cosa muy suya sygún lo que dyçen por acá. Ya estará sosegado lo de Ytalya pues dyçen a escryto el [Duque] de Saboya una carta con muchas sumysyones a don Pedro de Toledo. La paz de Françya está ya echa. Arto afrentosa es pero no an podydo açer otra cosa. Ella durará byen poco a my juyçyo. Cada dýa me haçe más lástyma la Reyna [Ana] que aun que sabe mucho a my juyçyo es muy nyña por otro cabo y no tyene quyen la adyestre como serýa menester. Yo le escrybo todas las beçes que puedo lo que me pareçe le puede estar byen y le debo mucho que me dyçen todos güelga de açer todo lo que le dygo. Çyerto yo la quyero como a hyja de su padre que es cuanto lo puedo encaresçer, y asý deseo que salga de manera que todos la adoren que por acá con un buen rostro se granjea más que con todo y con mostralle amor y afabylydad. Para deçyros la verdad, byen desbaratado me a pareçydo el aposento de Aranjues, a lo menos yo no perdyera el cor[r]edor por nada que syenpre me acuerdo lo que me e olgado en él. Byenen por la nobya y asý no puedo pasar de aquý, encomendadme a vuestras hijas y guarde os Dyos como deseo, de Brusselas, a 10 de mayo 1616. Isabel.

${ }_{174}$ María Josefa Pimentel y Girón, I duquesa de Huéscar, tercera esposa de Fadrique Álvarez de Toledo Enríquez (1537-1585), hijo y sucesor de Fernando Álvarez de Toledo, III duque de Alba (1507-1582). 1568).

175 Isabel de Valois, hija de Enrique II de Francia, fue la tercera esposa de Felipe II (1559-

176 Pedro Téllez Girón, duque de Osuna, virrey de Nápoles. 
XVIII. Carta de la Infanta Isabel al Marqués de Velada, Mariemont, 22 de julio de 1616, BL, Add. 28.698, fols. 218r.-219v.

Agradecimiento por las cartas recibidas. Lamenta el aislamiento que padece la reina Ana de Francia debido a la debilidad del embajador español el duque de Monteleón. Le han llegado noticias incluso de maltrato físico por parte del colérico Luis XIII.

Marqués, yo estaba para responderos muy despaçyo a vuestras cartas con el ordynaryo que le tengo por más syguro que los cor[r]eos y justamente a açertado a pasar este cor[r]eo de Yngalater[r]a que nos a oblygado a escrybyr y quytádome el tyenpo para responderos aora, en pudyendo y aquý sólo os agradeçeré el cuydado que tenéys de escrybyrme y deçyros cuánto güelgo syempre con vuestras cartas y cuando sé que bos y vuestros hyjos tenéys la salud que os deseo. Aquý la tenemos y my prymo está ya muy balyente de aber estado ocho dýas en la cama con la gota en una rodylla. Esto a estado ogaño más lyndo que nunca y aora es otra prymabera. Con aber llobydo a echo muy buena calor los más dýas y aún la açe.

De la Reyna de Françya abrá abydo aý cartas nuebas con fray Gregoryo ${ }^{177}$ y a my me tyenen lastymadýsyma cuán tremprano comyença sus trabaxos. Pyenso tyenen arta culpa los que an venydo con ella. Cosas an pasado ter[r]ybles y yo pyenso la matarán byen presto sy no se remedya. El Duque de Monteleón es demasyado de bueno para allý. Yo me le [he] embyado a quexar que aunque escrybe artas beçes sobre negoçyos jamás myenta a la Reyna. Yo pyenso lo açe por no deçyr lo que pasa, por no darnos pena. Çyerto yo la tengo byen grande pues llega el negoçyo a abella querydo. poner las manos su marydo. Esto sea para bos. Su cólera es ter[r]yble, como de tartamudo. Arto abrýa que deçyr pero no puedo pasar de aquý. A vuestras hyjas me encomyendo mucho y guarde os Dyos como deseo. De Marymont, a 22 de julyo 1616. Isabel.

177 Se trata del fraile mercedario Gregorio de Valencia, que actuó como agente diplomático y confidente de los archiduques para los asuntos relacionados con el norte de África. Tomó parte en las negociaciones con el judío norteafricano Samuel Pallache, embajador del rey de Marruecos. Véase García Arenal, Mercedes y Wiegers, Gerard: Entre el Islam y Occidente. Vida de Samuel Pallache, judío de Fez, Madrid, Siglo XXI Editores, 1999, pp. 136-139 y 195-204. 